\title{
Managing Imbalanced Supply Chain Relationships for Sustainability: A Power Perspective
}

\author{
Anne Touboulic (Corresponding author) \\ Logistics and Operations Management Section \\ Cardiff Business School \\ Cardiff University, Cardiff, UK \\ TouboulicAC@cardiff.ac.uk
}

Tel: $+44(0) 2920876570$

Fax: +44 (0)2920 874419

\section{Daniel Chicksand}

Operations and Information Management Group

Aston Business School

Aston University, Birmingham, UK

d.chicksand@aston.ac.uk

\section{Helen Walker}

Logistics and Operations Management Section

Cardiff Business School

Cardiff University, Cardiff, UK

WalkerHL@cardiff.ac.uk

Acknowledgements: This article reports on findings from a three-year research project funded by the UK Economic and Social Research Council (ESRC). 


\section{ABSTRACT}

This study adopts a power perspective to investigate sustainable supply chain relationships and specifically uses resource dependence theory (RDT) to critically analyze buyer-suppliersupplier relationships. Empirical evidence is provided, extending the RDT model in this context. The concept of power relationships is explored through a qualitative study of a multinational company and agricultural growers in the UK food industry that work together to implement sustainable practices. We look at multiple triadic relationships involving a large buyer and its small suppliers to investigate how relative power affects the implementation of sustainable supply-management practices. The study highlights that power as dependence is relevant to understanding compliance in sustainable supply chains and to identifying appropriate relationship-management strategies to build more sustainable supply chains. We show the influences of power on how players manage their relationships and how it affects organizational responses to the implementation of sustainability initiatives. Power notably influences the sharing of sustainability-related risks and value between supply chain partners. From a managerial perspective, the study contributes to developing a better understanding of how power can become an effective way to achieve sustainability goals. This paper offers insights into the way in which a large organization works with small and medium size enterprises (SMEs) to implement sustainable practices and shows how power managementthat is, the way in which power is used - can support or hinder effective cooperation around sustainability in the supply chain. 


\section{INTRODUCTION}

With growing concerns over the sustainability and ethicality of business practices, supply chain relationships have become even more critical. Companies face increasing pressure to account for the malpractices of their suppliers and sometimes their suppliers' suppliers. This idea of "boundaryless responsibility" (Amaeshi, Osuji, \& Nnodim, 2008) means that companies need to consider how they can achieve economic, social, and environmental goals through their entire supply chain (SC). Firms are challenged with managing their SC relationships in order to mitigate the reputational and operational risks that can emerge from unethical and unsustainable practices (Krause, Vachon, \& Klassen, 2009). The depth and quality of the relationship between a firm and its suppliers was the most commonly cited facilitator of sustainable supply chain management (SSCM) (Brammer, Hoejmose, \& Millington, 2011). Surveys of business executives reveal that SSCM is of critical importance in managers' agendas (Anonymous, 2010; Haanaes et al., 2011; Hopkins, 2009; Kiron, Kruschwitz, Haanaes, \& von Streng Velken, 2012). Hence, the importance of developing knowledge around what constitutes efficient relationship-management strategies for sustainability.

In this manuscript, we use Carter and Rogers's (2008) definition of SSCM as "the strategic, transparent integration, and achievement of an organization's social, environmental, and economic goals in the systemic coordination of key interorganizational business processes for improving the long-term economic performance of the individual company and its supply chains" (2008: 368). Their definition builds upon the triple-bottom-line view of sustainability (Elkington, 1998), which conceptualizes organizational performance as the management of not only economic but also environmental and social capital. This definition is also consistent with the argument that SSCM is a key relational capability (A. Paulraj, 
2011). It is necessary to understand relational antecedents and their impact on SSCM in order to fully comprehend how long-term sustainability performance may be achieved.

Previous research has put a strong emphasis on collaboration between SC partners to facilitate sustainability initiatives (e.g. Gold, Seuring, \& Beske, 2010; Seuring \& Müller, 2008). Several studies by Klassen and Vachon (Klassen \& Vachon, 2003; 2006, 2008; 2006; 2007; 2008) consider green supply chains (SC) and have shown that collaborative green practices and integration with suppliers were associated with higher performance. Other studies by Verghese and Lewis (2007) and Rao (2004) add further supporting evidence that SC partnerships and integration enhance environmental innovation and the greening of the production process. Improved trust as a result of SC collaboration enhances SSC performance through knowledge sharing and communication (Alvarez, Pilbeam, \& Wilding, 2010; Cheng, Yeh, \& Tu, 2008). Cooperation with suppliers has become viewed as a critical component of creating sustainable SCs (Pagell \& Wu, 2009).

In this study, we deviate from previous studies emphasizing collaboration by considering the importance of power differentials between supply chain members in achieving triple-bottom-line goals. In traditional SC literature, a significant amount of research has looked at the concept of power in buyer-supplier exchange (e.g. Benton \& Maloni, 2005; Cox, 2004a; Meehan \& Wright, 2012; Oliver, 1990). These studies share the view that power dynamics are central to understanding supply relationship-management practices. Terpend and Ashenbaum (2012) have shown that power affects different aspects of industrial relationships including trust, conflict levels, collaboration, commitment, and satisfaction. The role that power plays in buyer-supplier relationships is often perceived as being negative (Caniëls \& Gelderman, 2007; Nair, Narasimhan, \& Bendoly, 2011). When considering the shift from SCM to SSCM, relationship-management strategies may significantly change to accommodate the goals of sustainability with, for example, dominant 
buyers not exploiting their power over dependent suppliers but rather treating them like strategic partners (Pagell, Wu, \& Wasserman, 2010).

There is little research challenging the collaborative paradigm in SSCM, and power relationships remain underexplored (Hoejmose \& Adrien-Kirby, 2012; Helen Walker, Miemczyk, Johnsen, \& Spencer, 2012). This is surprising given that most research in the field considers the activities of large corporations often working with small suppliers at home or overseas to implement sustainable practices (Amaeshi, et al., 2008; Jeremy Hall, 2001; Lee \& Klassen, 2008; H. Walker \& Preuss, 2008). Arguably many case studies presented in the SSCM literature display some sort of power imbalance, which will not only determine who drives the agenda but also influence the implementation and outcomes of sustainability initiatives (Boyd, Spekman, Kamauff, \& Werhane, 2007; Jeremy Hall, 2001; Millington, 2008; E.R. Pedersen \& Andersen, 2006). Power inequalities are likely to influence the development of trust in relationships and, more generally, alter the dynamics of the exchange (Stephens, Fulk, \& Monge, 2009)

In this paper, we adopt a power perspective to better understand how such imbalanced relationships are managed in sustainable SCs. We draw upon resource dependence theory (RDT) and analyze the vertical relationships between a large buyer and its small suppliers and the horizontal relationships among these suppliers, working together to implement sustainability practices. Our study addresses the following research questions:

How do imbalanced SC power relationships affect the implementation of SSCM?

a. Does power imbalance act as a driver or barrier to SSCM?

b. How does the power differential influence the management of sustainability practices among the buyer and its suppliers?

We therefore make four main contributions. First, we make an original contribution to the field by offering an alternative view to the widely adopted collaborative paradigm and 
respond to calls for researching how power imbalance between buyer and supplier affects sustainability practice (Pullman, Maloni, \& Carter, 2009). Second, we provide practical insights about how relative power and dependence impact the management of interorganizational processes for implementing sustainability practices (Sarkis, Zhu, \& Lai, 2011). Third, our application of RDT to investigate SSCM practices is a response to calls for more theoretically grounded research in the field. Most SSCM studies fail to employ any theoretical lens (55\% according to Carter \& Easton, 2011) and remain largely descriptive (Hoejmose \& Adrien-Kirby, 2012; Helen Walker, et al., 2012). The theoretical contribution of our research goes beyond the traditional focal-firm perspective adopted in SSCM (Carter \& Easton, 2011; Carter \& Rogers, 2008) to encompass buyer-supplier-supplier relations. Fourth, we specifically address the concerns about the need to increase the application of RDT to study buyer-supplier relationships (Casciaro \& Piskorski, 2005), and specifically in SSCM (Carter \& Easton, 2011; Carter \& Rogers, 2008). RDT has been previously identified as relevant but relatively underutilized (Sarkis, et al., 2011).

The remainder of the paper is structured as follows. We start by presenting the theoretical foundation to our study through a discussion of the concept of power in SCs and explain our rationale for focusing on RDT and its relevance to SSCM. We then discuss the methodology adopted and present our findings regarding power/dependence and relationship management. Finally, we discuss our findings and their implications and draw conclusions.

\section{THEORETICAL FOUNDATION}

Many conceptualizations of power exist in the literature (Chicksand, 2009; Ireland \& Webb, 2007), in particular how power is exerted in organizations (Hardy \& Clegg, 1996; Marx, 1976; Thomas, Sargent, \& Hardy, 2010; Weber, 1978). Research has focused on sources of power (French \& Raven, 1959), and whether power is mediated or not (Benton \& Maloni, 2005; M. Maloni \& Benton, 2000). Provan (1980) distinguishes between potential and 
enacted power emerging from the dependencies between individuals and organizations. In considering the link between power and dependence in interorganizational relations (Gaski, 1984; Handley \& Benton, 2012), we specifically adopt RDT, which has evolved from the organizational power literature. From this theoretical perspective, the ability to influence another firm's behavior (i.e., power) requires this firm to have control over certain resources on which the other firm is dependent (Cox, 2007).

\section{Power: A Resource Dependence Perspective}

The literature on RDT has power at its heart, and organizational success in RDT is defined as power maximization (Ulrich \& Barney, 1984). Several authors have drawn attention to the limited amount of empirical work explicitly extending RDT (Casciaro \& Piskorski, 2005; Pfeffer \& Salancik, 2003) and argued that RDT needs continued exploration in order to remain relevant (Singh, Power, \& Chuong, 2011). We answer these various calls by adopting RDT in our study.

Interorganizational power is a relative concept, emerging from the specific context of a relationship, and it can serve as a way of managing the relationship (Chicksand, 2009; Cox, Ireland, Lonsdlale, \& Watson, 2002; Frazier, 1999). An organization's ability to exercise power over another actor will depend on the actor's dependence on the organization. In turn, the nature and availability of the resources controlled by the actors determine the degree of dependence experienced (Ramsay, 1996). No organization is self-sufficient, and therefore firms will seek to enter a relationship to be able to access resources they need to achieve their organizational outcomes. Interorganizational relations are formed to manage interdependence between organizations (Antony Paulraj \& Chen, 2007; Pfeffer \& Salancik, 1978; Singh, et al., 2011). There will be power imbalance (asymmetrical interdependence) if firm $\mathrm{A}$ is more dependent on firm B than B is on A. Power depends on the criticality of the resource 
(commercial and operational importance) and the availability of alternatives to source the same resource (scarcity) (Chicksand, 2009; Cox, et al., 2002).

RDT offers predictions with regard to actions organizations will take to manage dependence in terms of power use or power restructuring (Casciaro \& Piskorski, 2005). RDT recognizes the importance of external factors on organizational behaviors, and organizations can act to minimize uncertainty and dependence that emanate from the external environment (Hillman, Withers, \& Collins, 2009; Ulrich \& Barney, 1984).

\section{Power in Buyer-Supplier Relationships}

In buyer-supplier relationships with power imbalances, the dominant organization is likely to exercise its influence over the other party and act to maintain its power, whereas the weaker organization is more likely to comply to continue accessing resources (Gulati \& Sytch, 2007; Kumar, Scheer, \& Steenkamps, 1995; Zhu, Sarkis, Lai, \& Geng, 2008).

The powerful firm may act opportunistically (Frazier, 1999; Ireland \& Webb, 2007; Williamson, 1981), and make agreements that will favor its own interests or encourage suppliers to make the majority of investments or relationship specific adaptations (Casciaro \& Piskorski, 2005; Cox, Chicksand, \& Palmer, 2007; Ramsay, 1996). Powerful organizations are likely to resist entering long-term collaborative relationships, as it would signify a loss of power due to an increase in dependence (Casciaro \& Piskorski, 2005; Ramsay, 1996). Less powerful organizations might be reluctant to collaborate with powerful organizations, as they might not benefit from the exchange and become overreliant on a specific organization. This has been described as a 'treadmill to oblivion', whereby there is an expectation from suppliers to invest in continuous improvement with diminishing returns (Cox, et al., 2007).

Power imbalances may have a negative impact on interorganizational relationships, which can become less stable and less trusting (Heide, 1994; Kumar, et al., 1995). The exploitation of coercive power can undermine an organization's ability to achieve its goals 
and be "self-defeating in the long-run" (Kumar, 1996; M. Maloni \& Benton, 2000). A careful and controlled use of power can, however, promote SC integration and have positive effects on performance, providing the power holder understands its supply chain partners and the sources of their dependencies (M. Maloni \& Benton, 2000).

The work of Cox et al. (Cox, 2001; Cox, 2004a; Cox \& Chicksand, 2007a, 2007b, 2007c; Cox, et al., 2007; Cox, et al., 2002) provides a useful extension of RDT that enables not only mapping power dependencies in given relationships (balanced or imbalanced) but also measuring the consequences of those dependencies. Their work has shown that power is not static and that buyers and suppliers can use various strategies to alter the dependencies. Such strategies can help move, for example, from situations of buyer or supplier dominance to interdependence. They include seeking alternative and more buyers/suppliers, developing a closer relationship through long-term agreements, or engaging in joint product differentiation activities (Cox, 2001; Cox, et al., 2002). The power regimes perspective combines RDT, thinking from the transaction costs literature (Williamson, 1981), and the work of Porter (1985) as a mean of linking attributes of buyer and supplier power to relationshipmanagement styles. These are based upon the way that value is shared in the relationships (equal or unequal) and the nature of the working relationship (arms' length or collaborative).

Imbalanced power may result in an appropriation by the powerful player of the larger share of benefits resulting from the exchange (Casciaro \& Piskorski, 2005; Ramsay, 1996). This contrasts with cases of interdependence (i.e., cases in which parties are jointly dependent on each other), which can lead to more exchange stability and foster collaboration (Kumar, et al., 1995; Spekman, Kamauff Jr, \& Myhr, 1998). Awareness of the specificities of the business ties and relative power is key to developing suitable value-creating and -sharing strategies (Chicksand, Ramsay, \& Rehme, 2011)

\section{RELEVANCE OF A POWER PERSPECTIVE IN SSCM}


Organizational sustainability initiatives are concerned with the transformation of business strategies to respond to broader societal issues (Dunphy, Griffiths, \& Benn, 2007; Pagell, et al., 2010). Sustainable change, contrary to other change initiatives, is not bounded to the organizational realm but is linked to external social pressures (A. Paulraj, 2011). Sustainability literature views the organization as embedded in a network of stakeholders (Freeman, Wicks, \& Parmar, 2004), where changes in society's expectations affect an organization's license to operate (Porter \& Kramer, 2006). It has been argued that organizational sustainability, and therefore sustainability performance, can only be fully achieved if sustainability issues are addressed at the SC level (A. Paulraj, 2011; Lutz Preuss, 2005). SC activities are a critical source of value and competitive advantage for businesses (Burgess, Singh, \& Koroglu, 2006); thus, an organization's environmental and social performance is affected by that of its suppliers (Tate, Ellram, \& Kirchoff, 2010). Simpson and Power (2005) have shown that supply relationships "may present a key way for business to influence the sustainability of products and services."

While collaboration has been advocated as the best way to manage SC relationships for sustainability (e.g., Alvarez, Pilbeam, \& Wilding, 2010; Vachon \& Klassen, (2008), Verghese \& Lewis, 2007), it is interesting to note that most of SSCM literature tends to focus on the actions of large corporations. These large companies benefit from more resources at hand to address sustainability issues and are more exposed to external pressure (Zhu, et al., 2008). When ethical dilemmas arise in a SC, large multinationals are often held responsible for the behavior of their suppliers. In order to minimize the risk incurred by scandals in their SCs, these large companies will tend to act unilaterally and put pressure on their suppliers to adopt codes of conduct and more sustainable business practices (Jeremy Hall, 2001; Mollenkopf, Stolze, Tate, \& Ueltschy, 2010; E.R. Pedersen \& Andersen, 2006). This can be challenging for smaller suppliers that have limited capabilities (Lee, 2008; Esben Rahbek 
Pedersen, 2009). Rather than viewing such imbalanced SSCs from a collaborative paradigm, it seems relevant to explore power in SSC relationships and how imbalanced relationships are coordinated to achieve sustainability.

A number of authors have called for more research into the role of power, and imbalanced power in particular, in influencing SSC practices. Pedersen and Andersen (2006) identified bargaining power as an important mechanism to safeguard codes of conduct. They call for further exploration of the cases of SMEs, which also need safeguarding mechanisms but may lack the bargaining power and resources. Boyd et al. (2007) suggest investigating the impact and use of imbalanced power bases on the ability to establish CSR between SC partners. Pullman et al. (2009) call for further research into the impact of power influences in the SC on sustainability performance. In their view, power imbalance is highly relevant to segments of the food SC and will affect the sharing of sustainability practice costs and resulting performance (Pullman, et al., 2009: 49). Overall, relational exchanges in a SSC context are complex, and it may be too idealistic to view them solely from a collaborative perspective.

Power, as defined by RDT, helps us understand the choices on how to manage sustainability along the SC. Power imbalance can provide opportunities to facilitate the implementation and monitoring of socially and environmentally responsible SC practices (J. Hall, 2000; L. Preuss, 2001). A powerful buyer has a greater chance of successfully implementing SSC practices because it can enforce sustainability requirements and codes over its suppliers (Ciliberti, Groot, Haan, \& Pontrandolfo, 2009; Millington, 2008; Vurro, Russo, \& Perrini, 2009). This view of power as an enabler for SSCM has been contested. Boyd et al. (2007) argue that the powerful player seeking compliance and using coercive mechanisms can become an SC "bully" rather than a "champion." Hall and Matos (2010) 
show that power imbalance impedes interfirm learning and knowledge diffusion and undermines SSC policies.

\section{EXTENDING RDT TO SUSTAINABLE SC RELATIONSHIPS}

Managing SSC relationships raises some unique challenges, which lend themselves to a power perspective. Implementing SSCM requires stakeholder engagement and buy-in over time (Alvarez, et al., 2010) in order to perform, for example, social audits or environmental product development (Pagell \& Wu, 2009). There is an intrinsic interplay between power and trust in SSCM. Shifting from SCM to SSCM will thus lead companies to significantly rethink their relationship-management strategies to accommodate changes in the business landscape driven by sustainability needs (Pagell, et al., 2010).

RDT has been applied to SSCM in a limited context and has been used to explain variations between firm sizes in SSCM (Zhu, et al., 2008) and to explore the relationship between large corporations and SMEs, which often have limited capabilities to engage in SSCM (Lee \& Klassen, 2008; Esben Rahbek Pedersen, 2009). In this study, we adopt RDT to explore imbalanced buyer-supplier-supplier relationships in SSCM

We investigate how power plays out in SSCM by extending RDT to encompass all dimensions of the triple bottom line (economic, social, and environmental). A firm that is powerful in commercial terms (controlling critical economic resources) may find itself increasingly dependent on other organizations when it comes to controlling social and environmental resources. Relative power has an impact on how value is shared in a relationship (Cox, 2004b) and may be expressed as social and environmental value as well as economic value (Carter \& Rogers, 2008; Markley \& Davis, 2007). Power imbalance and interdependence affect the outcomes of a relationship (Casciaro \& Piskorski, 2005; Kumar, et al., 1995; Spekman, et al., 1998) and can influence SC partners in subtle ways (M. Maloni \& Benton, 2000; Provan, 1980). A powerful firm may resist a restructuring of dependencies and 
will employ mechanisms to maintain its power advantage (Casciaro \& Piskorski, 2005). But it is the dominant organization's choice whether to exercise this power (e.g., coercively to ensure compliance), and it may be advantageous to ensure suppliers remain in the relationship and act in a mutually beneficial manner (Belaya, Gagalyuk, \& Hanf, 2009).

This study makes a novel contribution by addressing the lack of empirical research into the effects of power on buyer-supplier-supplier relationships in SSCM. The following section outlines how the study was conducted.

\section{METHODOLOGY}

In this study, we adopt a case approach that employs a combination of different methods (Eisenhardt \& Graebner, 2007; Shah \& Corley, 2006), including collection of strategy, environmental, and CSR documents from organizations in the SC; participant observations; a workshop with suppliers; and semistructured interviews with key stakeholders. A qualitative case study has been chosen because we seek to explore the relational dynamics around the implementation of SSC practices and therefore require an in-depth approach (Miles \& Huberman, 1994; Yin, 2003). Case study research is a particularly suitable research strategy in the food sector because it allows capturing details, meanings, and social embeddedness (Hingley, 2005; Matopoulos, Vlachopoulou, Manthou, \& Manos, 2007). Power remains largely underinvestigated in SSC relationships, and the case method is appropriate to explore this complex phenomenon. It allows for situational and context-specific factors to be considered and for capturing the connectedness and embeddedness of the relationships (Mintzberg, 1983; Pfeffer, 1981; Voss, Tsikriktsis, \& Frohlich, 2002).

\section{Case Selection}

Our research questions emphasize the need to provide in-depth understanding of imbalanced power relationships and their impact on sustainability. Therefore, focusing on a single-case 
exemplar was appropriate. Choosing a single leading company for our research is in line with the theoretical sampling approach of the case study methodology (Eisenhardt, 1989). Despite the obvious limitation of generalizability advanced against single cases (Voss, et al., 2002), studying the case of a leading company often leads to useful insights for benchmarking purposes and provides the depth of observation required for an underexplored phenomenon (Alvarez, et al., 2010; Barratt, Choi, \& Li, 2011). Cases of single firms have been used in SSCM research for their longitudinal orientation and the access they offer to multiple contexts and units of analysis (e.g. Alvarez, et al., 2010; Byron, Ali, Anton, \& Tim, 2008; Sigala, 2008). We selected the case company Big Food (BF) for four reasons:

1. The multinational company is behind four of the UK market's leading consumer brands. It has been recognized for its proactive engagement around sustainability over the last 5 years. It is one of the FT500 companies and is ranked in the Dow Jones Sustainability Index. It has been a participant in the UN Global Compact since 2008 and is also an active member of the Sustainable Agriculture Initiative Platform (SAI) and of the Sustainable Food Lab.

2. The company operates in the food sector, which is theoretically relevant for investigating power imbalances, in particular when it comes to relationships between a large firm and its small agricultural suppliers (Pullman, et al., 2009).

3. The company initiated a number of UK-focused sustainability projects in 2010, specifically aimed at improving agricultural sustainability and hence requiring working with growers. BF has rolled out a number of projects to its suppliers, such as carbon and water management, and has worked in collaboration with consultancies and nongovernmental organizations (NGOs) to develop its strategy and tools. These projects constituted ideal settings to observe our phenomena. 
4. BF was interested in understanding how to better engage with its agricultural suppliers and offered access to key participants and decision makers. This represents a relatively rare opportunity to be in contact with relevant stakeholders and be able to follow the implementation and evolution of the projects and relationships in real time and not retrospectively.

We focused on the relationships between $\mathrm{BF}$ and 11 small agricultural suppliers in three distinct supply chains (see Figure 1). We were also able to observe horizontal supplier relationships, especially in the case of Food A as illustrated by the links between suppliers on Figure 1. We aimed at analyzing a number of relationships that would provide enough comparative evidence for our case without compromising on the depth of the findings. Suppliers were selected not because they were the "best-behaving suppliers", i.e. suppliers that were the most compliant and/or achieved the best results with regards to sustainability goals, but because they represented important suppliers in the different chains. Important suppliers were chosen in terms of share of supply, position as head of supplier groups, and/or relational history with $\mathrm{BF}$ (see Table 1). The suppliers included in this study (Table 1) represent $100 \%$ of supplier groups in both Food A and B, and there is only one supplier missing in Food C.

Insert Table 1 here

\section{Research Setting: Power and Sustainability in Food Supply Chains}

This study was conducted in the food sector, which lends itself to a power perspective on SSC relationships. Food SCs are often characterized by an imbalanced distribution of power (Hingley, 2005; Hingley \& Lindgreen, 2010). The sector is dominated by a relatively small number of large companies that exert a comparatively large control over the trade, production, and consumption of food and agricultural commodities (Henson \& Humphrey, 2010), which 
has been coined "buyer-driven (-ness)" (Gereffi, 1994). At the individual SC level, this means a power advantage for the "large" focal buyer, for example, food manufacturer or supermarket (Fearne, Duffy, \& Hornibrook, 2005; Hingley \& Lindgreen, 2010).

The power dynamics of food SCs have major implications on how sustainability practices are implemented and managed between SC members (Hingley, 2005). Food SCs are particularly critical with regard to sustainable development because of their distinctive social, economic, and environmental settings - for example, rural livelihoods, food security, and land use (M. J. Maloni \& Brown, 2006; Pullman, et al., 2009; Thompson \& Scoones, 2009). The food industry presents higher risks in the SC related to agricultural sustainability (Hamprecht, Corsten, Noll, \& Meier, 2005), accounts for a large number of sustainability standards (Henson \& Humphrey, 2008; Tallontire, 2007), and is highly exposed to public criticism (M. J. Maloni \& Brown, 2006). Companies have addressed these CSR issues by developing standards, certifications, or sustainability programs and defining new modes of governance of the production process (Henson \& Humphrey, 2008). The sharing of the costs and performance gains of these sustainability practices is likely to be impacted by the power imbalances characterizing food SCs (Cox, et al., 2007; Pullman, et al., 2009).

\section{Unit of Analysis}

Our level of analysis is the triad: buyer-supplier-supplier. Traditionally, power relationships are studied at the dyadic level between buyers and suppliers (Cox, 2004a; Kumar, 1996). Recently authors in SCM have argued that considering triads could help link the dyadic to the network level of analysis and account for structural embeddedness (T. Choi \& Kim, 2008; T. Y. Choi \& Wu, 2009; Wilhelm, 2011). As well as investigating dyadic buyer-supplier relationships, we added a further analysis of our findings at the horizontal level of relationships between suppliers, which we were able to observe during meetings, during the workshop, and in the interviews. Supplier-supplier relations have strong strategic 
implications for a focal firm, as they influence the process and outcomes of buyer-supplier relationships (Wu \& Choi, 2005). They represent a link between what the focal firm can control (the design of the network) and the more emergent, invisible part of the network (T. Y. Choi \& Dooley, 2009). Relationships between suppliers are more complex and dynamic than vertical buyer-supplier relationships (Wu \& Choi, 2005). They are characterized by coopetition - that is, simultaneous competition and cooperation-and can influence how power plays out in the network (Wilhelm, 2011; Wu \& Choi, 2005). Organizations performing well in sustainability may adopt strategies to manage the interaction between their suppliers (Pagell \& Wu, 2009). The triadic level is underrepresented in SSCM research (Carter \& Easton, 2011), and we therefore make a pertinent contribution to the field.

\section{Insert Figure 1 here}

\section{Data Collection}

We conducted semistructured interviews with representatives of both the buying and selling organizations. Within the large customer firm, purchasing, agriculture, and sustainability managers were chosen as key informants because of their position as "boundary spanners" (Andersen \& Kumar, 2006; Eltantawy, Fox, \& Giunipero, 2009; D. F. Simpson \& Power, 2005; Wilhelm, 2011) and their level of experience regarding the specific relationships. Within the supplier firms, we interviewed people with the highest level of expertise regarding the relationship with the customer, such as owners, managing directors, or BF customer relationship managers. The supplier firms are either small or medium enterprises and very often family owned. Theoretical saturation also guided the number of interviews included in this study, and we stopped interviewing when we felt that we were not gaining additional insights (Kaufmann \& Denk, 2011). 
The total number of interviews included in this study is 32 (Table 2). Three of the interviews at the buying firm have been counted three times, since the managers discussed suppliers across the three different supply chains. Interviews lasted between 30 minutes and 2 hours. They were all digitally recorded and subsequently transcribed and were kept anonymous due to commercial sensitivity. Follow-up phone conversations and emails allowed for clarifications and additional details. Transcripts were sent to participants for feedback.

We developed a semistructured interview protocol, as it allows for both focus and flexibility (Gilham, 2005) and ensures that interviewees have freedom to develop their answers. We constructed the questions around two dimensions: power/dependence and relationship management for SSCM, allowing us to explore manifestations of power in the structure and transaction processes of the relationship (Premkumar \& Ramamurthy, 1995: 307). Within these two dimensions of power/dependence and relationship management, we developed several interview themes drawing on the literature (Appendix A) that we then formulated as questions in the semistructured interview protocol (Appendix B). Questions were adapted for the buyer and supplier sides.

The interview protocol was refined through discussions between the authors and piloted with two individuals. It was then further reviewed after the first three interviews. For example, in addition to asking the interviewee's own definition of SSCM, we also provided the definition we use in this paper in order to clarify our focus on the three dimensions of the triple bottom line.

\section{Data Analysis}


We followed several steps to analyze the data. First, each relationship was evaluated in terms of power/dependence and whether it could be categorized as buyer dominance, supplier dominance, independence, or interdependence (Table 3).

Insert Table 3 here

Responses regarding relationship management were analyzed according to themes (Appendix A) in order to explore manifestations of power in the implementation of sustainable practices in the SC. We analyzed whether the existence of a power imbalance meant that the powerful player used power through different relational mechanisms and in what ways it was used. We also analyzed positive or negative attitudes from the parties under influence and if there were any signs of resistance to change. We looked at how equally the risks and benefits from engaging in sustainability projects were shared between buyer and supplier. Evidence from statements about investments, contractual terms, price, and impact on business performance were used to support our judgment as to who benefits or suffers more in the relationship. Horizontal relationships between suppliers in the different SCs were analyzed subsequently, looking at both the buyer's strategic intent for these relationships and relational patterns observed between suppliers during fieldwork. Once all relationships were analyzed individually, we used tables to draw comparisons between them and let patterns and differences emerge.

\section{Rigor and Quality}

The overall "trustworthiness" of our research (Lincoln \& Guba, 1985; Shah \& Corley, 2006) was ensured through various methods described in Table 4. In particular, the combined expertise of the authors in SSCM and SC power concepts has ensured critical review throughout the research process. We analyzed the interview data using a grid based upon 
interview themes as detailed in the Appendix, thereby ensuring a common objective frame of reference for the authors. Finally, we focused on specific buyer-supplier interaction but protected the informants' confidentiality to ensure the credibility and dependability of the information collected.

\author{
Insert Table 4 here
}

\title{
FINDINGS
}

\section{Measuring Power Imbalance}

The interview findings regarding criticality and scarcity have allowed us to map the different relationships on the power/dependence matrix (Table 3). The analysis of the power relationships is presented in Table 5.

Insert Table 5 here

All the relationships reflect an existing power imbalance between customer and supplier. Most relationships between BF and its SME suppliers fall into the buyer dominance category. Only three relationships can be categorized as supplier dominance. Details and evidence of the dominant relationship types are presented in Table 6 .

\section{Insert Table 6 here}

\section{Buyer Dominance}

We found that all relationships with Food A suppliers were dominated by the buyer. BF accounts for a relatively high proportion of supplier revenue, between $10 \%$ for supplier A2 and $90 \%$ for supplier A3. Suppliers of Food A mentioned the lack of alternatives to sell their 
agricultural products, which results in a high level of dependence on the buyer. This lock-in is reinforced by the capital requirements of growing crop A. The buyer has more flexibility regarding its supply base, with more than 100 growers producing the crop. Supplier A1 and Supplier C2 can actually be considered dedicated suppliers, as the former supplies crop A to BF only and the latter was created at the request of BF to provide a secure supply of crop C.

Suppliers' accounts of tense price negotiations and tough contractual agreements provide further evidence of buyer dominance. Although most of the relationships have been ongoing for several decades, contracts have been signed every year, with a push from the buyer to drive prices down. BF is reluctant to enter long-term agreements with the suppliers. The supplier base is managed through supplier groups, which nominally appear to be aimed at strengthening the connection between suppliers and buyers. However, in practice, this has primarily allowed $\mathrm{BF}$ to exert more operational control over these dedicated suppliers through, for example, more stringent quality requirements, vendor assurance audits, and a transfer of operational responsibilities to the growers (e.g., washing, storage, quality control).

It was evident however that there were varying degrees of buyer dominance between BF and their suppliers. This had an impact on the level of SSCM compliance. In relationships with the most significant power differentials (e.g. A.1.1, A.1, A3), the suppliers were more inclined to comply and respond to BFs' demands for fear of losing their contract. This translated into, for example, supplier's quickly sending back filled in questionnaires to appear responsive and acquiescent. These suppliers were also more willing to trial some of BF's new initiatives such as testing alternative crop varieties. The degree of power therefore provided $\mathrm{BF}$ with more potential to impose their sustainability agenda. In the relationships with a lesser degree of buyer dominance (e.g. A.2, A.6), suppliers complained about having to comply with multiple sustainability demands from different customers. As they were less reliant on BF they were able to postpone responding to BF's demands, for example, providing carbon 
measurement information. The relationship with BF provided these suppliers with opportunity to develop an expertise on sustainability, which they were then able to use to leverage better contracts with other customers.

\section{Supplier Dominance}

Suppliers B1, B2, and C1 are in a dominant position compared to BF mainly because of the flexibility of their positions. While they are happy to maintain the relationship with BF, they have a number of alternative supply options for their crop, and in the case of B, they are able to exit the relationship without having to incur additional costs. This means that BF finds itself in a position in which it has to rely on these suppliers to obtain the crops that are central to its new "healthy and sustainable" product portfolio.

Evidence of supplier dominance is also visible in the contractual arrangements. In these cases, the suppliers seem reluctant to enter into long-term agreements with BF because this may present a risk to them, as it would mean being locked in to BF.

\section{Shifting Levels of Dependence}

The findings presented above primarily reflect the power/dependence structure of the relationships in commercial terms. There is evidence suggesting that the recent inclusion of sustainability in the relationship has led to a restructuring of dependencies. Figure 2 illustrates evidence of the shift to interdependence.

$$
\text { Insert Figure } 2 \text { here }
$$

BF is becoming increasingly reliant on its suppliers to achieve its sustainability targets. When talking about the necessity to reduce carbon emissions and improve watermanagement practices, the agricultural team expressed concerns about BF's ability to reach 
its targets, considering that it was the growers who were responsible for managing the environmental resources.

"It is not us delivering because we are not farming anything, we don't farm things."(Agronomist at Big-Food)

This highlights the fact that the growers have privileged access to the natural environment compared to the buyer. The suppliers also deal with social issues such as managing seasonal/temporary labor hired for harvesting. The growers are therefore very critical for the buyer in terms of environmental and social sustainability in the SC.

The intermediary role played by first-tier suppliers is another important aspect, which revealed that BF's dependence was increasing when it came to SSCM.

"The big concern from me is how you get out to all the growers because this is the agriculture team [pointing at 3 members] so physically we cannot do it ourselves." (Head of agriculture team at $B F$ )

The relationships with the first-tier suppliers are key to ensure engagement with sustainability farther up the chain. One of the suppliers highlighted that "good growers" were disappearing, and it was in BF's interest to try and retain them through their first-tier relationships.

"Our job is to cascade that down to the growers further up the chain and generate the interest and the understanding and how important they find it." (Supplier A1)

Similarly, there was evidence that dominant suppliers' dependence on BF was increasing in the context of managing environmental and social resources. In particular, as the food industry is becoming stricter regarding environmental and social standards, the suppliers see the relationship with $\mathrm{BF}$ as a critical way to access the knowledge and skills they will need in the market. 
"Discussing sustainability with BF had an impact on us in terms of making us think differently about where our industry is headed (...) I think that BF are several steps ahead of everyone else. And we're very much looking at the relationship that we have with BF now as being probably quite a good insight into the way we will trade with a lot more people in the future." (Supplier B1)

In addition, dominant suppliers were incentivized to enter longer-term agreements with BF. From BF's point of view this was a way to ensure the continuity of supply for their healthy product portfolio. From the suppliers' perspective there was a price advantage in entering into a longer-term agreement, despite the relative loss of power.

"We've been able to get a slightly better price in return for giving that commitment." (Supplier B2)

The relationships have been mapped according to the power dynamics observed, as shown in Figure 3. The analysis presented in Table 5 illustrates that the power dynamics within the relationships were not always the same. Some relationships were clearly aligned with the classification criteria shown in Table 3 and the critical themes as identified in Table 6. These relationships were therefore positioned toward the boundaries of the quadrants, demonstrating a greater degree of buyer or supplier dominance, i.e. RA1 and RB1. In contrast, those relationships that showed only a partial fit were positioned relative to how closely they matched the profiles described in Table 3 i.e. RA2 and RB2. This process required interpretation by the researchers, as the existing power model (Cox, 2001; Cox, 2004a) did not incorporate varying degrees of power imbalance within the four broad categories.

The analysis has therefore captured the degree of power imbalance within the relationships, rather than fitting them into one of four broad categories (i.e. buyer dominance, 
supplier dominance, interdependence, independence). Having a more nuanced approach to the categorization of power relationships is a significant finding, but one which requires fuller investigation and explanation in the future. The dotted arrows indicate that as the relationships evolve to encompass sustainability goals, there is evidence that dependencies are shifting toward interdependence. Regardless of whether the starting point is supplier dominance or buyer dominance, through the actions of the different players or simply as a result of increasing dependence on now-key resources (i.e. $1^{\text {st }}$ order schemes shown in Figure 2), there is a convergence toward interdependence. A move to interdependence for either dominant buyers or suppliers will result in a loss of power. However, in return it is likely that there will be advantages such as preferential terms, increased security, knowledge exchange, more significant joint learning opportunities and hence a greater potential to fulfill the sustainability agenda.

Insert Figure 3 here

\section{Horizontal Relationships and Power}

Analyzing the relationships between suppliers reveals that the buyer's strategic intent is to try and manage the relationships between the suppliers, especially in the case of Food A, to achieve both its sustainability goals (encourage them to collaborate) and more short-term economic goals (foster competition between them). However, as the suppliers are increasingly collaborating, they become more conscious of their own power over the buyer and become more resistant to changing their practices. Bargaining power shifts in favor of the suppliers when considering the horizontal relationships. Relationships between suppliers in Food A are coopetitive, and $\mathrm{BF}$ attempts to advance sustainability while encouraging price competition. Coopetition is visible through the expectations from BF for suppliers to collaborate and share 
learning on carbon and water management within the group but compete on price; and when competing suppliers share the cost of investing in new environmentally friendly storage facilities. This approach implies that suppliers in Food A are willing to maintain a long-term relationship and comply with the buyer's requirements while tolerating a short-termist behavior regarding contracts and prices. As it is often difficult for suppliers to understand the antagonistic pressures from the buyer, this leads to resentment and solidarity among them despite competition.

In this study there is a clear power imbalance between BF and individual suppliers. Although this power differential still remains, when we consider the suppliers as a group (i.e. Food A) there are some subtle changes in how power manifests itself in the relationship. While on an individual basis the suppliers find it difficult to resist the demands from BF, they have a more effective voice as a group. When BF purchased drip irrigation equipment and gave it to the suppliers, as a group they discussed BF's initiative and chose not to install the technology. This was because they had not been consulted before the purchase and the solution would add extra costs to their operations. Without the forum to be able to talk over this issue, suppliers of Food A would have been unlikely to resist this initiative. Clearly the supplier groups are a setting imposed by BF but the non-expected side effect of this is the emerging sense of group power when it comes to questions of sustainability, which does not exist on an individual supplier basis.

There is a high risk of relationship failure in Food A, as the buyer continues to exploit its power position to try and manage the relationships between its suppliers. Characteristics of horizontal relationships are summarized in Table 7.

Insert Table 7 here

Power Influences in Relationship Management for Sustainability 
We found several indications of how power affects the management of relationships around sustainability issues. We have labeled these "power influences on SSC relationships" and classify them according to which dimension of the relationship they affect. Evidence of these power influences is presented in Table 8 .

\section{Insert Table 8 here}

BF has been using its powerful position to advance its sustainability agenda with the growers. The terms employed by members of the agriculture and purchasing team within $\mathrm{BF}$ confirm the idea of a push for sustainability and the necessity for the suppliers to comply with requirements. There is evidence of coercive power in the contractual arrangements and in the one-way communication, with emphasis on monitoring and the lack of involvement of the suppliers in planning and setting the sustainability goals.

Power imbalance is also reflected in the unequal sharing of investments and risks in relation to sustainability (e.g., storage investments required from the growers, climate change risks for growers). This inequality is reinforced by the lack of alignment between the commercial goals ("more forensic on costs") and the sustainability agenda of the buyer. The suppliers have a challenge to find the necessary resources to comply with the sustainability requirements. As its dependence on suppliers increases, BF is reluctant to enter long-term agreements, which could provide further engagement on sustainability.

The use of power to implement sustainability appears to have its limits, as BF is faced with growing resistance and resentment from the suppliers. All the suppliers interviewed have expressed their desire to see greater demonstration by the buyer of the mutuality of the relationship and greater recognition of the specific efforts they make and difficulties they face in addressing sustainability issues. Power imbalance has impacted how sustainability goals have been defined, with little consideration for the growers' perspective and expertise. This 
has reinforced suppliers' negative feelings about the quality of the relationship with the buyer. This resistance has led to a lot of uncertainty for BF in terms of whether it will achieve its sustainability goals (e.g., carbon reduction). For instance, the buyer faces uncertainty regarding the accuracy of the environmental data it requires from the suppliers and finds it difficult to move beyond minimal levels of compliance.

Interestingly, when dealing with dominant suppliers, there was a minimal level of engagement around sustainability in the relationships, which are more focused on commercial aspects and price. BF has made recent attempts to try and restructure the relationships with the suppliers in its favor by trying to negotiate longer-term agreements. This is a way of reducing the suppliers' bargaining power while advancing sustainability. Conversely, weaker suppliers can also adopt the same strategy to increase BFs' dependence on the supplier and increase their bargaining power. It is evident therefore that power relationships are dynamic and that buyers and suppliers can employ strategies to restructure the dependencies.

In terms of outcomes, BF has managed to significantly reduce the carbon emissions $(\approx 2 \%)$ and water consumption $(\approx 14 . \%)$ in its SCs. Despite this progress, BF is not sure of being able to reach its goal of halving $\mathrm{CO}_{2}$ by 2015. Suppliers are required to measure the carbon impact of their activities through a computer-based tool. However, gathering the data represent big challenges. BF employees send out many reminders and have to constantly chase suppliers, who view these requirements as additional hurdles with no additional benefits. Social initiatives have not been implemented because they are viewed as more difficult to measure and less relevant to agricultural suppliers in the UK.

\section{DISCUSSION AND IMPLICATIONS}

\section{Theoretical Implications}

The results from this study provide four key findings, which have then led to formulating six propositions. First, the research shows that a powerful organization can drive sustainability in 
its SC. Dependent suppliers in this situation have little choice but to comply with the buyer's requirements and are obliged to invest specifically in the relationship to become more sustainable. These findings are in line with previous work, which suggested that buyer power represents a resource to force supplier compliance to sustainability requirements (Ciliberti, et al., 2009; J. Hall, 2000; Ireland \& Webb, 2007; L. Preuss, 2001). Buyer power constitutes an effective tool for sustainability, as a power imbalance in favor of a large proactive buyer allows them to define and drive the sustainability agenda on dependent suppliers, ensure compliance, and stimulate collaboration around sustainability between their network of suppliers. This is especially relevant in the case of small suppliers whose engagement in sustainability may be limited without the pressure from a powerful customer, as shown in previous research (Lee \& Klassen, 2008; Millington, 2008; Esben Rahbek Pedersen, 2009). There were additional indications in our study that the degree of power imbalance between the buyer and supplier affects the level of supplier compliance and willingness to engage in sustainability projects. Specifically, in cases where there was strong buyer dominance, the suppliers were more likely to comply whereas in less extreme cases suppliers were more likely to be resistant. This leads to our first two propositions.

Proposition 1a: Buyer dominance is positively associated with the adoption and implementation of SSCM.

Proposition 1b: The degree of buyer dominance is positively associated with the level of supplier compliance to SSCM.

However, when the power imbalance is in favor of the supplier, the engagement around sustainability in the relationship remains minimal. This corroborates the view that relatively independent suppliers do not feel as much pressure to comply with the buyer's requirements (Casciaro \& Piskorski, 2005). This creates a high level of uncertainty for a 
buyer looking to achieve sustainability goals. As a consequence, such imbalanced relationships may be characterized by attempts from the dependent buyer to restructure the relationship to advance its sustainability goals (e.g., seek longer-term agreements, implement knowledge-sharing processes). This leads to the second proposition.

Proposition 2: Supplier dominance is negatively associated with the adoption and implementation of SSCM.

A powerful buyer's demanding sustainability requirements, combined with adversarial commercial practices, is likely to create confusion and uncertainty for suppliers. In the long term, it can also undermine the long-term economic sustainability of smaller suppliers, as they bear a higher share of risks and costs of the sustainability initiatives, proportionally to their available resources, while benefiting less from their adoption than the buyer does. This can be likened to a 'technological treadmill to oblivion' as observed in previous research in other food SCs and contexts (Cox, et al., 2007). In addition, attempts by the buyer to use its powerful position to advance sustainability result in a perception by suppliers of a degradation of the quality of the relationships, particularly as communication and decision making appear rather unilateral. As this feeling becomes shared among the majority of suppliers in the SC, a sense of solidarity emerges, and suppliers become increasingly reluctant to cooperate with the buyer's requirements. Our research therefore reveals that supplier-supplier relations in SSCs emerge beyond the control of the powerful buyer and will have an effect on the overall sustainability performance, hence supporting previous findings on horizontal relationships (T. Choi \& Kim, 2008; T. Y. Choi \& Dooley, 2009; T. Y. Choi \& Wu, 2009; Wu \& Choi, 2005). This can help answer the question of where the boundaries of a buyer's responsibility lie in a supply network, highlighted by Amaeshi et al. (2008). These aspects constitute potential barriers to the advancement of SSCM in the future and lead to the following two propositions. 
Proposition 3a: The use of buyer power on dependent suppliers creates resistance, which impair the long-term achievement of sustainability goals.

Proposition 3b: Interaction between suppliers favors the emergence of a shared feeling of resistance, which counteracts the use of buyer power for SSCM.

The study revealed that levels of dependence between players might shift when considering sustainability. A dominant buyer can become increasingly dependent on its suppliers to access and control environmental and social resources, which are critical to achieving SSC goals. In this case, joint dependence becomes higher and provides a foundation for both parties to develop longer-term organizational arrangements, which align commercial and sustainability goals. However, as predicted by past research using RDT, the dominant buyer is likely to resist loss of discretion to maintain its bargaining power and advantageous exchange conditions (Casciaro \& Piskorski, 2005). The resulting confrontational atmosphere undermines collaboration on sustainability practices, as parties have difficulty creating mutually beneficial relationship conditions (Belaya, et al., 2009). This supports our earlier suggestion that RDT needs to be extended in SSCM to account for not only economic but also environmental and social dimensions of the relationships. These findings lead to our last proposition.

Proposition 4: Levels of dependence and power shift in favor of suppliers when considering the buyer's necessity to access environmental and social resources to implement SSCM.

\section{Managerial Implications}

This study has implications for buyers and SC managers seeking to advance the sustainability agenda. We found that a powerful buyer has the opportunity to enforce and monitor its sustainability requirements with suppliers. In addition, the ability of a buyer to understand and manage relationships among its suppliers is critical to advance sustainability. 
However, there were indications that power may become a controversial tool for SSCM and impair further engagement for sustainability. Coercive power may only lead to compliance with minimum requirements because it affects suppliers' commitment (Boyd, et al., 2007; Handley \& Benton, 2012), and suppliers within the same network may develop a sense of solidarity against the buyer.

Power imbalance can make it difficult to balance economic with environmental and social goals in the SC. An unanticipated consequence of commercial buyer power can mean that the long-term economic sustainability of smaller suppliers is undermined. While large companies may have access to more resources to engage with the sustainability agenda, small firms have a critical role to play in ensuring that sustainability goals are met. They often constitute the link between the large company and critical environmental and social resources and also are connected to other parties in the network. Managers need take into account the responsibility held by small firms in order to develop appropriate risk- and value-sharing strategies.

The evolution toward a relationship for sustainability requires aligning commercial and sustainability goals, as well as acknowledging that dependence on suppliers increases due to the imperative of managing environmental and social resources. It is important for managers to understand the sources of power and dependences in their SC for power to become an effective tool to advance sustainability.

\section{LIMITATIONS AND FUTURE DIRECTIONS}

We have developed a number of propositions from our study, and an obvious avenue for future research would be to further test them. We recognize the limited generalizability of our findings, as we report on a single embedded case of a large focal company working with multiple small suppliers in the UK food sector. 
The food industry presents relatively specific features with regard to sustainability and power relationships, and it would be interesting to extend the research to other sectors, across different geographical locations, and between overseas buyer-supplier relationships. A longitudinal study of a number of SC relationships could provide deeper insights into the evolution of SC relationships for sustainability.

In addition, further work is needed to explore the implications of the degree of power imbalance in relationships. As has been suggested by this research, in relationships where there was significant buyer dominance, rather than weaker buyer dominance, it was more likely that the supplier would fully comply with the SSCM agenda.

We see additional opportunities to apply and extend RDT in SSCM research. For instance, combining RDT with stakeholder theory would gain insights into how firms manage and prioritize stakeholder dependencies in the SC. RDT could be used to explore the political mechanisms through which organizations create conditions that are more favorable to their sustainability interests (e.g., lobbying government for transition to low-carbon technologies).

\section{CONCLUSION}

In this paper, we offer new evidence into the management of triadic relationships in SSCM. We have made a novel contribution by adopting a power perspective and extended the RDT model to explore SSC relationships. This study contributes to the advancement of SSCM research by offering a theoretically underpinned approach to empirically investigate the implementation of sustainability practices between a large focal firm and its small suppliers.

Our findings support RDT in explaining how commercial dependence can foster compliance and how the dominant player can use power to drive sustainability in the SC by pushing the cost of sustainability onto the weaker party while gaining the bigger share of performance gains. In this sense, power can undermine the advancement of sustainability in the SC, as it is likely to create resistance from collaborating parties but also weaken their 
ability to engage in longer-term sustainability strategy by reducing their economic bottom line. Horizontal relationships among suppliers, although creating a platform for the buyer to encourage supplier collaboration on environmental and social projects, can create concerns for the long-term pursuit of sustainability goals as suppliers develop a sense of group power and combine forces against the buyer.

Finally, our findings suggest that the evolution from a commercially focused relationship to one that encompasses sustainability issues may result in a change in the levels and nature of dependencies. This transition may lead to conflict, as the existing powerful player will resist entering into longer agreements. This situation is a potential barrier to further engagement between parties to address key sustainability issues.

Overall, we have shown that power imbalance is not necessarily detrimental to the advancement of SSCM. Rather, it is crucial that managers develop a clear understanding of the power/dependence structure of their supply chain relationships in order to identify appropriate management strategies that can facilitate the advancement of environmental, social, and economic goals.

\section{REFERENCES}

Alvarez, G., Pilbeam, C., \& Wilding, R. (2010). Nestlé Nespresso AAA sustainable quality program: an investigation into the governance dynamics in a multi-stakeholder supply chain network. Supply Chain Management: An International Journal, 15(2), 165-182.

Amaeshi, K. M., Osuji, O. K., \& Nnodim, P. (2008). Corporate Social Responsibility in Supply Chains of Global Brands: A Boundaryless Responsibility? Clarifications, Exceptions and Implications. Journal of Business Ethics, 81(1), 223-234.

Andersen, P., \& Kumar, R. (2006). Emotions, trust and relationship development in business relationships: A conceptual model for buyer-seller dyads. Industrial Marketing Management, 35(4), 522-535.

Anonymous. (2010). Is Your Supply Chain Sustainable? Harvard Business Review, 88(10), 74.

Barratt, M., Choi, T. Y., \& Li, M. (2011). Qualitative case studies in operations management: Trends, research outcomes, and future research implications. Journal of Operations Management, 29, 329-342.

Belaya, V., Gagalyuk, T., \& Hanf, J. (2009). Measuring Asymmetrical Power Distribution in Supply Chain Networks: What Is the Appropriate Method? Journal of Relationship Marketing, 8(2), 165-193.

Benton, W., \& Maloni, M. (2005). The influence of power driven buyer/seller relationships on supply chain satisfaction. Journal of Operations Management, 23(1), 1-22. 
Boyd, D. E., Spekman, R. E., Kamauff, J. W., \& Werhane, P. (2007). Corporate Social Responsibility in Global Supply Chains: A Procedural Justice Perspective. Long Range Planning, 40(3), 341-356.

Brammer, S., Hoejmose, S., \& Millington, A. (2011). Managing sustainable global supply chains: A systematic review of the body of knowledge. In N. f. B. Sustainability (Ed.): Network for Business Sustainability.

Burgess, K., Singh, P. J., \& Koroglu, R. (2006). Supply chain management: a structured literature review and implications for future research. International Journal of Operations \& Production Management, 26(7), 703-729.

Byron, K., Ali, Q., Anton, K., \& Tim, C. (2008). In pursuit of a sustainable supply chain: insights from Westpac Banking Corporation. Supply Chain Management: An International Journal, 13(3), 175-179.

Caniëls, M. C. J., \& Gelderman, C. J. (2007). Power and interdependence in buyer supplier relationships: A purchasing portfolio approach. Industrial Marketing Management, 36(2), 219-229.

Carey, J. W., Morgan, M., \& Oxtoby, M. J. (1996). Intercoder agreement in analysis of responses to open-ended interview questions: examples from tuberculosis research. Cultural Anthropology Methods, 8(3), 1-5.

Carter, C. R., \& Easton, P. L. (2011). Sustainable supply chain management: evolution and future directions. International Journal of Physical Distribution \& Logistics Management, 41(1), 46-62.

Carter, C. R., \& Rogers, D. S. (2008). A framework of sustainable supply chain management: moving toward new theory. International Journal of Physical Distribution \& Logistics Management, 38(5), 360-387.

Casciaro, T., \& Piskorski, M. J. (2005). Power Imbalance, Mutual Dependence and Constraint Absorption: A Closer Look at Resource Dependence Theory. Administrative Science Quarterly, 50, 167-199.

Cheng, J.-H., Yeh, C.-H., \& Tu, C.-W. (2008). Trust and knowledge sharing in green supply chains. Supply Chain Management: An International Journal, 13(4), 283-295.

Chicksand, D. (2009). Creating a sustainable UK farming and food industry: An analysis of partnership thinking as a solution to the problems in the UK farming and food industry. Doctor of Philosophy, University of Birmingham, Birmingham.

Chicksand, D., Ramsay, J., \& Rehme, J. (2011). Sharing value in business relationships: a theoretical model. Paper presented at the Annual IPSERA Conference, Maastricht, Netherlands.

Choi, T., \& Kim, Y. (2008). Structural embeddedness and supplier management: A network perspective. Journal of Supply Chain Management, 44(4), 5-13.

Choi, T. Y., \& Dooley, K. (2009). Supply networks: Theories and models. Journal of Supply Chain Management, 45(3), 25-26.

Choi, T. Y., \& Wu, Z. (2009). Triads in supply networks: theorizing buyer-supplier-supplier relationships. Journal of Supply Chain Management, 45(1), 8-25.

Ciliberti, F., Groot, G. d., Haan, J. d., \& Pontrandolfo, P. (2009). Codes to coordinate supply chains: SMEs' experiences with SA8000. Supply Chain Management: An International Journal, 14(2), 117-127.

Cox, A. (2001). Understanding buyer and supplier power: A framework for procurement and supply competence. Journal of Supply Chain Management, 37(2), 8-15.

Cox, A. (2004a). The art of the possible: relationship management in power regimes and supply chains. Supply Chain Management: An International Journal, 9(5), 346-356.

Cox, A. (2004b). Business relationship alignment: on the commensurability of value capture and mutuality in buyer and supplier exchange. Supply Chain Management: An International Journal, 9(5), 410-420.

Cox, A. (2007). Transactions, power and contested exchange: towars a theory of exchange in business relationships. International Journal of Procurement Management, 1(1-2), 38-59.

Cox, A., \& Chicksand, D. (2007a). Are win-wins feasible? Power relationship in agri-food supply chains and markets. In D. Burch \& G. Lawrence (Eds.), Supermarkets and Agri-food Supply Chains (pp. 74-99). Cheltenham: Edward Elgar Publishing 
Cox, A., \& Chicksand, D. (2007b). The power regime perspective: power and business choices in food and farming supply chains. Management Online Review.

Cox, A., \& Chicksand, D. (2007c). The power regimes methodology: Differentation strategies for achieving sustainable business success. Management Online Review.

Cox, A., Chicksand, D., \& Palmer, M. (2007). Stairways to heaven or treadmills to oblivion?: Creating sustainable strategies in red meat supply chains. British Food Journal, 109(9), 689-720.

Cox, A., Ireland, P., Lonsdlale, C., \& Watson, G. (2002). Supply chains, markets and power: Mapping buyer and supplier power regimes. London: Routledge.

Dunphy, D., Griffiths, A., \& Benn, S. (2007). Organizational Change for Corporate Social Responsibility (2nd ed.). Oxon: Routledge.

Eisenhardt, K. M. (1989). Building theories from case study research. Academy of Management Review, 14(4), 532-550.

Eisenhardt, K. M., \& Graebner, M. E. (2007). Theory building from cases: opportunities and challenges. Academy of Management Journal, 50(1), 25-32.

El-Ansary, A. I., \& Stern, L. W. (1972). Power measurement in the distribution channel. Journal of Marketing Research, 9, 47-52.

Elkington, J. (1998). Cannibals with Forks: The Triple Bottom Line of the 21st Century Business. Oxford: Capstone Publishing.

Eltantawy, R. A., Fox, G. L., \& Giunipero, L. (2009). Supply management ethical responsibility: reputation and performance impacts. Supply Chain Management: An International Journal, 14(2), 99-108.

Commission recommendation of 6 May 2003 concerning the definition of micro, small and mediumsized enterprises (2003).

Fearne, A., Duffy, R., \& Hornibrook, S. (2005). Justice in UK supermarket buyer-supplier relationships: an empirical analysis. International Journal of Retail \& Distribution Management, 33(8), 570-582.

Frazier, G. L. (1999). Organizing and Managing Channels of Distribution. Journal of the Academy of Marketing Science, 27(2), 226-240.

Freeman, R. E., Wicks, A., C., \& Parmar, B. (2004). Stakeholder Theory and "The Corporate Objective Revisited". Organization Science, 15(3), 364.

French, J. R. P., \& Raven, B. (1959). The bases of social power. In D. Cartwright (Ed.), Studies in social power (pp. 259-269). Ann Arbor: Institute for social research.

Fynes, B., De Búrca, S., \& Marshall, D. (2004). Environmental uncertainty, supply chain relationship quality and performance. Journal of Purchasing \& Supply Management, 10(4/5), 179-190.

Gaski, J. F. (1984). The theory of power and conflict in channels of distribution Journal of Marketing, 48, 9-29.

Gereffi, G. (1994). Capitalism, development and global commodity chain. In L. Sklair (Ed.), Capitalism and Development (pp. 211-231). London: Routledge.

Gilham, B. (2005). Research interviewing: the range of techniques. New York: OUP.

Gold, S., Seuring, S., \& Beske, P. (2010). Sustainable supply chain management and interorganizational resources: a literature review. Corporate Social Responsibility and Environmental Management, 17(4), 230-245.

Gulati, R., \& Sytch, M. (2007). Dependence asymmetry and joint dependence in interorganizational relationships: Effects of embeddedness on a manufacturers performance in procurement relationships. Administrative Science Quarterly, 52, 32-69.

Haanaes, K., Balagopal, B., Arthur, D., Kong, M. T., Velden, I., Kruschwitz, N., \& Hopkins, M. (2011). First Look: The Second Annual Sustainability and Innovation Survey. MIT Sloan Management Review, 52(2), 77-83.

Hall, J. (2000). Environmental supply chain dynamics. Journal of Cleaner Production, 8, 455-471.

Hall, J. (2001). Environmental Supply-Chain Innovation. Greener Management International(35), 105.

Hall, J., \& Matos, S. (2010). Incorporating impoverished communities in sustainable supply chains. International Journal of Physical Distribution \& Logistics Management, 40(1/2), 124-147.

Hamprecht, J., Corsten, D., Noll, M., \& Meier, E. (2005). Controlling the sustainability of food supply chains. Supply Chain Management: An International Journal, 10(1), 7-10. 
Handley, S. M., \& Benton, W. C. (2012). Mediated power and outsourcing relationships. Journal of Operations Management, 30(3), 253-267.

Hardy, C., \& Clegg, S. R. (1996). Some dare call it power. In S. Clegg, C. Hardy \& W. Nord (Eds.), Handbook of Organization Studies (pp. 622-641). London: Sage.

Heide, J. B. (1994). Interorganizational governance in marketing channels. Journal of Marketing, 58, 71-85.

Heide, J. B., \& John, G. (1990). Alliances in industrial purchasing: The determinants of joint action in buyer-supplie relationships. Journal of Marketing Research, 27, 24-36.

Henson, S., \& Humphrey, J. (2008). Understanding the complexities of private standards in global agri-food chains.

Henson, S., \& Humphrey, J. (2010). Understanding the complexities of private standards in global agri-food chains as they impact developing countries. Journal of Development Studies, 46(9), 1628-1646.

Hillman, A. J., Withers, M. C., \& Collins, B. J. (2009). Resource Dependence Theory: A Review. Journal of Management, 35(6), 1404-1427.

Hingley, M. (2005). Power imbalanced relationships: cases from UK fresh food supply. International Journal of Retail \& Distribution Management, 33(8), 551-569.

Hingley, M., \& Lindgreen, A. (2010). Living with power imbalance in the food supply chain. In C. Mena \& G. Stevens (Eds.), Delivering Performance in Food Supply Chains (pp. 37-61). Cambridge: Woodhead Publishing.

Hoejmose, S. U., \& Adrien-Kirby, A. J. (2012). Socially and environmentally responsible procurement: A literature review and future research agenda of a managerial issue in the 21st century. Journal of Purchasing \& Supply Management, 18(4), 232-242.

Hopkins, M. S. (2009). Long-viewed, see-through, collaborative and retooled. MIT Sloan Management Review, 51(1), 45-46.

Ireland, R., \& Webb, J. (2007). A multi-theoretic perspective on trust and power in strategic supply chains. Journal of Operations Management, 25(2), 482-497.

Kaufmann, L., \& Denk, N. (2011). How to demonstrate rigor when presenting grounded theory research in the supply chain management literature. Journal of Supply Chain Management, 47(4), 64-72.

Kiron, D., Kruschwitz, N., Haanaes, K., \& von Streng Velken, I. (2012). Sustainability nears a tipping point. MIT Sloan Management Review, 53(2), 68-75.

Klassen, R., \& Vachon, S. (2003). Collaboration and evaluation in the supply chain: The impact on plant-level environmental investment. Production and Operations Management, 12(3), 336352.

Krause, D. R., Vachon, S., \& Klassen, R. D. (2009). Special topic forum on sustainable supply chain management: Introduction and reflections on the role of purchasing management. Journal of Supply Chain Management, 45(4), 18-25.

Kumar, N. (1996). The power of trust on manufacturer-retailer relationships. Harvard Business Review, Nov-Dec, 92-106.

Kumar, N., Scheer, L. K., \& Steenkamps, J. B. E. (1995). The effects of perceived interdependence on dealer attitudes. Journal of Marketing Research, 32, 348-356.

Lee, S.-Y. (2008). Drivers for the participation of small and medium-sized suppliers in green supply chain initiatives. Supply Chain Management: An International Journal, 13(3), 185-198.

Lee, S.-Y., \& Klassen, R. D. (2008). Drivers and Enablers That Foster Environmental Management Capabilities in Small- and Medium-Sized Suppliers in Supply Chains. Production and Operations Management, 17(6), 573-586.

Lincoln, Y., \& Guba, E. (1985). Naturalistic Inquiry. Beverly Hills, CA: Sage.

Lindgreen, A. (2001). A framework for studying relationship marketing dyads. Qualitative Market Research, 4(2), 75-87.

Maloni, M., \& Benton, W. C. (2000). Power influences in the supply chain. Journal of Business Logitics, 21(1), 49-73.

Maloni, M. J., \& Brown, M. E. (2006). Corporate Social Responsibility in the Supply Chain: An Application in the Food Industry. Journal of Business Ethics, 68(1), 35-52. 
Markley, M. J., \& Davis, L. (2007). Exploring future competitive advantage through sustainable supply chains. International Journal of Physical Distribution \& Logistics Management, 37(9), 763-774.

Marx, K. (1976). Capital. Harmondsworth: Penguin.

Matopoulos, A., Vlachopoulou, M., Manthou, V., \& Manos, B. (2007). A conceptual framework for supply chain collaboration: empirical evidence from the agri-food industry. Supply Chain Management: An International Journal, 12(3), 177-186.

Meehan, J., \& Wright, G. H. (2012). The origins of power in buyer-seller relationships. Industrial Marketing Management, 41(4), 669-679.

Miles, M. B., \& Huberman, A. M. (1994). Qualitative Data Analysis (2nd ed.). London: Sage.

Millington, A. (2008). Responsibility in the supply chain. In A. Crane, A. McWilliams, D. Matten, J. Moon \& D. S. Siegel (Eds.), The Oxford Handbook of Corporate Social Responsibility (pp. 363). Oxford: OUP.

Mintzberg, H. (1983). Power in and around organizations. Englewood Cliffs, N.J: Prentice-Hall.

Mollenkopf, D., Stolze, H., Tate, W. L., \& Ueltschy, M. (2010). Green, lean, and global supply chains. International Journal of Physical Distribution \& Logistics Management, 40(1/2), 14-41.

Monczka, R. M., Petersen, K. J., Handfield, R. B., \& Ragatz, G. L. (1998). Success factors in strategic supplier alliances: The buying compnay perspective. Decision Sciences, 29(3), 553-577.

Nair, A., Narasimhan, R., \& Bendoly, E. (2011). Coopetitive buyer-supplier relationship: An investigation of bargaining power, relational context, and investment strategies. Decision Sciences, 42(1), 93-127.

Oliver, C. (1990). Determinants of interorganizational relationships: Integration and future directions. Academy of Management Review, 15(2), 241-265.

Pagell, M., \& Wu, Z. (2009). Building a more complete theory of sustainable supply chain management using case studies of 10 exemplars Journal of Supply Chain Management, 45(2), 37-56.

Pagell, M., Wu, Z., \& Wasserman, M. E. (2010). Thinking differently about purchasing portfolios: An assessment of sustainable sourcing Journal of Supply Chain Management, 46(1), 57-73.

Paulraj, A. (2011). Understanding the relationships between internal resources and capabilities, sustainable supply management and organizational sustainability. Journal of Supply Chain Management, 47(1), 19-37.

Paulraj, A., \& Chen, I. J. (2007). Environmental Uncertainty and Strategic Supply Management: A Resource Dependence Perspective and Performance Implications. Journal of Supply Chain Management, 43(3), 29-42.

Pedersen, E. R. (2009). The many and the few: rounding up the SMEs that manage CSR in the supply chain. Supply Chain Management: An International Journal, 14(2), 109-116.

Pedersen, E. R., \& Andersen, M. (2006). Safeguarding corporate social responsibility (CSR) in global supply chains: how codes of conduct are management in buyer-supplier relationships. Journal of Public Affairs, 6((3/4)), 228-240.

Pfeffer, J. (1981). Power in organizations. Marshfield: Pitman Pub.

Pfeffer, J., \& Salancik, G. R. (1978). The external control of organizations: a resource dependence perspective. New York: Harper \& Row.

Pfeffer, J., \& Salancik, G. R. (2003). The external control of organizations: a resource dependence perspective. Stanford: Stanford University Press.

Porter, M. E. (1985). Competitive advantage: Creating and sustaining superior performance. New York: The Free Press.

Porter, M. E., \& Kramer, M. R. (2006). Strategy and society: The link between competitive advantage and corporate social responsibilty. Harvard Business Review, 84(12), 78-92.

Premkumar, G., \& Ramamurthy, K. (1995). The role of interorganizational and organizational factors on the decision mode for adoption of interorganizational systems. Decision Sciences, 26(3), 303-336.

Preuss, L. (2001). In dirty chains? Purchasing and greener manufacturing. Journal of Business Ethics, $34,345-359$.

Preuss, L. (2005). Rhetoric and reality of corporate greening: a view from the supply chain management function. Business Strategy \& the Environment, 14(2), 123-139. 
Provan, K. G. (1980). Recognizing, measuring, and interpreting the potential/enacted power distinction in organizational research. Academy of Management Review, 5(4), 549-559.

Pullman, M. E., Maloni, M. J., \& Carter, C. R. (2009). Food for thought: Social versus environmental sustainability practices and performance outcomes Journal of Supply Chain Management, 45(4), 38-54.

Ramsay, J. (1996). Power measurement. European Journal of Purchasing and Supply Management, $2(2 / 3), 129-143$.

Rao, P. (2004). Greening production: a South-East Asian experience. International Journal of Operations \& Production Management, 24(3), 289-320.

Sarkis, J., Zhu, Q., \& Lai, K.-h. (2011). An organizational theoretic review of green supply chain management literature. International Journal of Production Economics, 130(1), 1-15.

Seuring, S., \& Müller, M. (2008). From a literature review to a conceptual framework for sustainable supply chain management. Journal of Cleaner Production, 16(15), 1699-1710.

Shah, S. K., \& Corley, K. G. (2006). Building better theory by bridging the quantitative-qualitative divide. Journal of Management Studies, 43(8), 1821-1835.

Sigala, M. (2008). A supply chain management approach for investigating the role of tour operators on sustainable tourism: the case of TUI. Journal of Cleaner Production, 16(15), 1589-1599.

Simpson, D., Power, D., \& Samson, D. (2007). Greening the automotive supply chain: a relationship perspective. International Journal of Operations \& Production Management, 27(1), 28-48.

Simpson, D. F., \& Power, D. J. (2005). Use the supply relationship to develop lean and green suppliers. Supply Chain Management: An International Journal, 10(1), 60-68.

Singh, P. J., Power, D., \& Chuong, S. C. (2011). A resource dependence theory perspective of ISO 9000 in managing organizational environment. Journal of Operations Management, 29(1-2), 49-64.

Spekman, R. E., Kamauff Jr, J. W., \& Myhr, N. (1998). An empirical investigation into supply chain management: A perspective on partnerships. International Journal of Physical Distribution \& Logistics Management, 28(8), 630-650.

Stephens, K. J., Fulk, J., \& Monge, P. R. (2009). Constrained choices in alliance formations: Cupids and organizational marriages. Human Relations, 62(4), 501-536.

Tallontire, A. (2007). CSR and regulation: towards a framework for understanding private standards initiatives in the agri-food chain. Third World Quarterly, 28(4), 775-791.

Tate, W. L., Ellram, L. M., \& Kirchoff, J. F. (2010). Corporate social responsibility reports: A thematic analysis related to supply chain management. Journal of Supply Chain Management, 46(1), 19-44.

Terpend, R., \& Ashenbaum, B. (2012). The intersection of power, trust and supplier network size: implications for supplier performance. Journal of Supply Chain Management, 48(3), 52-77.

Thomas, R., Sargent, L. D., \& Hardy, C. (2010). Managing Organizational Change: Negotiating Meaning and Power-Resistance Relations. Organization Science, 22(1), 22-41.

Thompson, J., \& Scoones, I. (2009). Addressing the dynamics of agri-food systems: an emerging agenda for social science research. Environmental Science \& Policy, 12(4), 386-397.

Ulrich, D., \& Barney, J. B. (1984). Perspectives in organizations: Resource dependence, efficiency, and population. Academy of Management Review, 9(3), 471-481.

Vachon, S., \& Klassen, R. (2006). Green project partnership in the supply chain: the case of the package printing industry. Journal of Cleaner Production, 14(6-7), 661-671.

Vachon, S., \& Klassen, R. (2008). Environmental management and manufacturing performance: The role of collaboration in the supply chain. International Journal of Production Economics, 111(2), 299-315.

Vachon, S., \& Klassen, R. D. (2006). Extending green practices across the supply chain: The impact of upstream and downstream integration. International Journal of Operations \& Production Management, 26(7), 795-821.

Vachon, S., \& Klassen, R. D. (2007). Supply chain management and environmental technologies: the role of integration. International Journal of Production Research, 45(2), 401-423.

Vachon, S., \& Klassen, R. D. (2008). Environmental management and manufacturing performance: The role of collaboration in the supply chain. International Journal of Production Economics, 111(2), 299-315. 
Verghese, K., \& Lewis, H. (2007). Environmental innovation in industrial packaging: a supply chain approach. International Journal of Production Research, 45(18/19), 4381-4401.

Voss, C., Tsikriktsis, N., \& Frohlich, M. (2002). Case research in operations management. International Journal of Operations \& Production Management, 22(2), 195.

Vurro, C., Russo, A., \& Perrini, F. (2009). Shaping Sustainable Value Chains: Network Determinants of Supply Chain Governance Models. Journal of Business Ethics, 90, 607-621.

Walker, H., Miemczyk, J., Johnsen, T., \& Spencer, R. (2012). Sustainable procurement: Past, present and future. Journal of Purchasing \& Supply Management, 18(4), 201-206.

Walker, H., \& Preuss, L. (2008). Fostering sustainability through sourcing from small businesses: public sector perspectives. Journal of Cleaner Production, 16(15), 1600-1609.

Weber, M. (Ed.). (1978). Economy and Society: An Outline of Interpretive Sociology. Berkeley: University of California Press.

Wilhelm, M. M. (2011). Managing coopetition through horizontal supply chain relations: linking dyadic and network levels of analysis. Journal of Operations Management, 29(7), 663-676.

Williamson, O. E. (1981). The economics of organization: the transaction cost approach. The American Journal of Sociology, 87(3), 548-577.

Wu, Z., \& Choi, T. (2005). Supplier-supplier relationships in the buyer-supplier triad: Building theories from eight case studies. Journal of Operations Management, 24(1), 27-52.

Yin, R. K. (2003). Case study research: Designs and methods (3rd ed.). Thousand Oaks, CA: Sage

Zhu, Q., Sarkis, J., Lai, K.-h., \& Geng, Y. (2008). The role of organizational size in the adoption of green supply chain management practices in China. Corporate Social Responsibility and Environmental Management, 15(6), 322-337.

\section{APPENDICES}

\section{APPENDIX A: INTERVIEW THEMES}

\section{Theme \\ Power/Dependence \\ Description}

Criticality

Scarcity

Construct

Relationship history

Contractual arrangements

Implementation process \& monitoring

Communication

Commitment

Planning \& goal setting

Problem resolution
The more critical the resource for an actor, the more dependent this actor will be on the resource provider.

If little or no alternative exists, the higher the level of dependence.

Relationship Management for SSCM Description

The history of interaction between partners is likely to influence present conditions and future exchange.

Understanding the contractual arrangements as formal interfirm governance mechanisms revealing the relationship orientation (adversarial, collaborative, etc.). Terms and enforcement of contracts can be influenced by the power structure of the relationship and reveal the equal or unequal sharing of costs and benefits.

Understanding governance mechanisms in place to reduce opportunistic behaviors and information asymmetry. Evaluation is viewed as an important mechanism in SSCM and, in particular, supplier assessments are often conducted to increase performance. Also indicates use of compliance and engagement mechanisms.

Evaluate the communication and information-sharing processes in place in a given relationship. The quantity and quality of communication impacts the quality of the relationship. Also serves to understand the level of interaction (one-way, two-way communication, type of information exchanged).

Dimension that shows the willingness of both buyers and suppliers to cooperate and exert efforts for the relationship. Relationship-specific investments and adaptation are reflections of commitment. Power use influences the level of commitment of partners.

This shows the extent to which partners cooperate in activities (level of joint and individual activities) such as development and design of sustainability programs. It also reveals the time orientation of the relation (short or long term).

The problem- and conflict-resolution techniques will influence the quality of

\section{Literature}

(Casciaro \& Piskorski, 2005;

Chicksand, 2009; Cox \&

Chicksand, 2007c)

\section{Literature}

(Benton \& Maloni, 2005; Heide \& John, 1990; Wu \& Choi, 2005)

(Benton \& Maloni, 2005; Chicksand, 2009; Frazier, 1999;

Monczka, Petersen, Handfield, \& Ragatz, 1998; D. Simpson,

Power, \& Samson, 2007)

(Chicksand, 2009; Frazier, 1999; Heide \& John, 1990; D. Simpson, et al., 2007)

(Benton \& Maloni, 2005; Frazier, 1999; Fynes, De Búrca, \& Marshall, 2004; Lindgreen, 2001; Monczka, et al., 1998)

(Benton \& Maloni, 2005;

Chicksand, 2009; Frazier, 1999; Fynes, et al., 2004; Lindgreen, 2001; Monczka, et al., 1998; D. Simpson, et al., 2007)

(Benton \& Maloni, 2005; ElAnsary \& Stern, 1972; Frazier, 1999; Fynes, et al., 2004; Heide \& John, 1990; Lindgreen, 2001) (Benton \& Maloni, 2005; 
Sharing of benefits \& risks

Continuity/future expectations the relationship and performance. The way problems are addressed reveals if there are coercive influences or more constructive joint approaches.

Level to which costs and performance gains of the relationship are shared between partners. Understanding if relationship-specific investments and adaptation are equally or unequally shared.

This measures both parties' expectations of future interactions. It shows the perceptions of the durability of the relationship. This is a future-oriented dimension, which complements the historical duration dimension that looks at past association.
Chicksand, 2009; Lindgreen,

2001; Monczka, et al., 1998)

(Benton \& Maloni, 2005;

Chicksand, 2009; Pullman, et al., 2009)

(Heide \& John, 1990)

\section{APPENDIX B: INTERVIEW PROTOCOL}

\section{A. General/Background}

A.1 Background on organization, position, job title, and responsibilities.

A.2 What is your understanding of sustainability and sustainable supply chain management in particular?

\section{B. Power/Dependence}

B.1 Criticality

B.1.1 How critical is this buyer/supplier in your overall business (commercially and operationally)?

B.1.2 (Supplier) How much does this buyer represent (\%) in your total turnover?

B.1.3 How much does the relationship with this supplier/buyer affect your environmental and social

B.2 Scarcity performance?

B.2.1 (Supplier) How many alternative buyers (existing or potential) do you have for this product?

B.2.2 (Buyer) How many existing and potential suppliers do you have for this item?

\section{Relationship Management for SSCM}

\section{C.1 History}

C.1.1 Can you tell me more about your relationship history with this buyer/supplier?

C.2 Contractual arrangements

C.2.1 Could you describe your contractual arrangements with this buyer/supplier? (Length, terms, negotiation)

C.2.2 Are there any sustainability requirements in your contract? (Examples)

C.3 Implementation process and monitoring

C.3.1 Can you give examples of sustainability projects you have been involved in with this buyer/supplier?

C.3.2 In general, how are sustainability initiatives implemented and monitored?

C.4 Communication

C.4.1 How often do you communicate/interact with this buyer/supplier?

C.4.2 Could you describe how you communicate with this buyer/supplier about sustainability?

\section{C.5 Commitment}

C.5.1 How committed are you to working with this buyer/supplier to implement a sustainable strategy?

C.5.2 Do you invest specifically in this relationship to facilitate the implementation of sustainability initiatives?

C.6 Planning and goal setting

C.6.1 Could you describe how decisions about the planning, development, and implementation of sustainability initiatives are made?

C.6.2 How are goals regarding sustainability set?

\section{C.7 Problem resolution}

C.7.1 Can you give me an example of sustainability-related project that has been particularly challenging?

C.7.2 In general, if there is a problem, how is it addressed? (Examples)

C.8 Sharing of benefits and risks

C.8.1 (Buyer) How do you support the implementation of sustainability projects with this supplier?

C.8.2 (Supplier) How are you supported to implement sustainability projects with this buyer?

C.8.3 Can you give me an example of a particularly successful initiative?

C.8.4 Overall, how would you evaluate your working relationship with this buyer/supplier regarding sustainability?

C.8.5 How has working on sustainability affected your relationship?

C.8.6 How has working on sustainability with this buyer/supplier influenced your business?

(Performance, financial, nonfinancial aspects)

\section{Conclusion: Future and Mutual Expectations}

D.1 What do you expect now and in the future from your relationship with this buyer/supplier regarding sustainability in particular? 
D.2 How essential is your relationship with this buyer/supplier in the future success of your business?

\section{TABLES}

Table 1: Description of Participating Companies

\begin{tabular}{|c|c|c|c|c|c|c|c|c|}
\hline & Description & Ownership & $\begin{array}{c}\% \text { turnover } \\
\text { attributed to } \\
\text { BF }\end{array}$ & $\begin{array}{c}\text { Annual } \\
\text { Turnover } \\
2010\end{array}$ & $\begin{array}{l}\text { Number of } \\
\text { Employees }\end{array}$ & $\begin{array}{l}\text { Length of } \\
\text { Relation } \\
\text { With BF }\end{array}$ & $\begin{array}{c}\text { Size } \\
\text { (European } \\
\text { Commission, } \\
\text { 2003) }\end{array}$ & $\begin{array}{c}N \\
\text { Interviewees }\end{array}$ \\
\hline Big Food & $\begin{array}{c}\text { Multinational food \& } \\
\text { drinks manufacturing } \\
\text { company }\end{array}$ & Public & N/A & $\$ 58 b n$ & $>5,000 \mathrm{UK}$ & - & Large & 10 \\
\hline $\begin{array}{l}\text { Supplier } \\
\quad \text { A1 }\end{array}$ & $\begin{array}{l}\text { Local merchant, } \\
\text { supplier and packer of } \\
\text { crop A }\end{array}$ & $\begin{array}{l}\text { Private } \\
\text { (family) }\end{array}$ & $35 \%$ & $<£ 35 \mathrm{~m}$ & $<250$ & $>40$ years & Medium & 2 \\
\hline A1.1 & $\begin{array}{l}\text { Local vegetable and } \\
\text { cereal farmer }\end{array}$ & $\begin{array}{l}\text { Private } \\
\text { (family) }\end{array}$ & $35 \%$ & $<£ 500 \mathrm{k}$ & $<10$ & $>10$ years & Micro & 1 \\
\hline A2 & $\begin{array}{l}\text { European vegetable and } \\
\text { cereal farming group }\end{array}$ & Private & $10 \%$ & $<£ 30 \mathrm{~m}$ & $<250$ & $>40$ years & Medium & 1 \\
\hline A3 & $\begin{array}{l}\text { Local vegetable and } \\
\text { cereal farmer }\end{array}$ & $\begin{array}{l}\begin{array}{l}\text { Private } \\
\text { (family) }\end{array} \\
\end{array}$ & $90 \%$ & $<£ 3 \mathrm{~m}$ & $<50$ & $>30$ years & Small & 1 \\
\hline A4 & $\begin{array}{c}\text { Local vegetable and } \\
\text { cereal farmer and } \\
\text { merchant }\end{array}$ & $\begin{array}{l}\text { Private } \\
\text { (family) }\end{array}$ & $20 \%$ & $<£ 5 \mathrm{~m}$ & $<50$ & $>30$ years & Small & 2 \\
\hline A5 & $\begin{array}{c}\text { Local grower group of } \\
\text { crop A }\end{array}$ & Private & $40 \%$ & $<£ 8 \mathrm{~m}$ & $<50$ & $>40$ years & Small & 2 \\
\hline A6 & $\begin{array}{l}\text { Local vegetable farmer } \\
\text { and packer }\end{array}$ & $\begin{array}{l}\text { Private } \\
\text { (family) }\end{array}$ & $40 \%$ & $<£ 40 \mathrm{~m}$ & $<250$ & $>30$ years & Medium & 1 \\
\hline B1 & $\begin{array}{l}\text { Regional agricultural } \\
\text { merchant and supplier }\end{array}$ & $\begin{array}{l}\text { Private } \\
\text { (family) }\end{array}$ & $3 \%$ & $<£ 40 \mathrm{~m}$ & $<250$ & $>20$ years & Medium & 2 \\
\hline B2 & $\begin{array}{c}\text { Local vegetable and } \\
\text { cereal farmer }\end{array}$ & $\begin{array}{l}\text { Private } \\
\text { (family) }\end{array}$ & $10 \%$ & $<£ 8 \mathrm{~m}$ & $<10$ & $>10$ years & Small & 1 \\
\hline C1 & Local crop C merchants & Private & $3 \%$ & $<£ 8 \mathrm{~m}$ & $<50$ & $>10$ years & Small & 1 \\
\hline $\mathrm{C} 2$ & Local crop C producer & $\begin{array}{l}\text { Private } \\
\text { (family) }\end{array}$ & $40 \%$ & $<£ 8 \mathrm{~m}$ & $<50$ & $>30$ years & Small & 1 \\
\hline
\end{tabular}

Table 2: List of Expert Interviews by Supply Chain

\begin{tabular}{|c|c|c|c|}
\hline Supply Chain & $\begin{array}{c}\text { Number of } \\
\text { Relationships }\end{array}$ & $\begin{array}{c}\text { Number of } \\
\text { Interviews at } \\
\text { Supplying Firms }\end{array}$ & $\begin{array}{c}\text { Number of } \\
\text { Interviews at } \\
\text { Buying Firm }\end{array}$ \\
\hline FOOD A & 7 & 10 & 7 \\
\hline FOOD B & 2 & 3 & 5 \\
\hline FOOD C & 2 & 2 & 5 \\
\hline Total & $\mathbf{1 1}$ & $\mathbf{1 5}$ & $\mathbf{2}$ \\
\hline $\begin{array}{c}\text { Total number of } \\
\text { interviews }\end{array}$ & \multicolumn{3}{|c|}{$\mathbf{3 2}$} \\
\cline { 2 - 4 } & \multicolumn{2}{|c}{}
\end{tabular}

Tables 3: Power Relationships Types and Classification Criteria (Source: Adapted from Chicksand, 2009)

\begin{tabular}{|c|c|c|}
\hline HIGH & $\begin{array}{l}\text { Buyer Dominance } \\
\text { Buyer power is high when the dependence on } \\
\text { the supplier is low, that is, criticality of the } \\
\text { resource is relatively low (low operational and } \\
\text { commercial importance) and the scarcity of } \\
\text { alternative is low (i.e., availability of other } \\
\text { suppliers). Supplier power is low because the } \\
\text { buyer is very critical for the supplier and there } \\
\text { is no or little alternative to supply somewhere } \\
\text { else. }\end{array}$ & $\begin{array}{l}\text { Independence } \\
\text { Situation in which both buyer and supplier show } \\
\text { a low level of dependence on each other (low } \\
\text { levels of resource criticality and low levels of } \\
\text { scarcity). }\end{array}$ \\
\hline LOW & Interdependence & Supplier Dominance \\
\hline
\end{tabular}




\begin{tabular}{|l|l|l|}
\hline $\begin{array}{l}\text { Situation in which both buyer and supplier } \\
\text { show a high level of dependence on each other } \\
\text { (high levels of resource criticality and high } \\
\text { levels of scarcity). }\end{array}$ & $\begin{array}{l}\text { Buyer power is low when the dependence on the } \\
\text { supplier is high, that is, criticality of the } \\
\text { resource is relatively high and the scarcity of } \\
\text { alternative is high (i.e., limited availability of } \\
\text { other suppliers). Supplier power is high because } \\
\text { the buyer is not critical for the supplier and } \\
\text { there are alternatives/substitutes available for } \\
\text { the supplier. }\end{array}$ \\
LOW & \multicolumn{1}{c|}{ HIGH } \\
\hline
\end{tabular}

Table 4: Methods for Ensuring Trustworthiness Throughout the Research Process

\begin{tabular}{|c|c|c|c|c|c|}
\hline & \multirow[b]{2}{*}{ Criterion } & \multicolumn{4}{|c|}{ Research Phases } \\
\hline & & Design & Case Selection & Data Collection & Data Analysis \\
\hline$\bullet$ & Credibility & $\begin{array}{l}\text { Theoretical framework } \\
\text { Adoption of constructs } \\
\text { identified in previous } \\
\text { research }\end{array}$ & $\begin{array}{l}\text { Choice of leading } \\
\text { company in FTSE500 } \\
\text { and Dow Jones } \\
\text { Sustainability Index }\end{array}$ & $\begin{array}{l}\text { Multiple informants } \\
\text { Triangulation of } \\
\text { data sources } \\
\text { Extended period of } \\
\text { fieldwork }\end{array}$ & $\begin{array}{l}\text { Combination of } \\
\text { researchers' } \\
\text { experiences in SSCM } \\
\text { and power } \\
\text { Transcripts sent to } \\
\text { participants for } \\
\text { feedback }\end{array}$ \\
\hline$\bullet$ & Transferability & $\begin{array}{l}\text { Description of sampling } \\
\text { strategy } \\
\text { Selection of leading } \\
\text { company }\end{array}$ & $\begin{array}{l}\text { Detailed description of } \\
\text { research setting and } \\
\text { participating companies }\end{array}$ & $\begin{array}{l}\text { Detailed notes of } \\
\text { events and } \\
\text { observations }\end{array}$ & $\begin{array}{l}\text { Description of concepts } \\
\text { and categories } \\
\text { Within- and cross-case } \\
\text { analysis }\end{array}$ \\
\hline$\bullet$ & Dependability & Case study protocol & Theoretical sampling & $\begin{array}{l}\text { Interview protocol } \\
\text { developed } \\
\text { iteratively } \\
\text { Confidentiality of } \\
\text { participants }\end{array}$ & $\begin{array}{l}\text { Intercoder agreement } \\
\text { reached* } \\
\text { Grid of analysis }\end{array}$ \\
\hline$\bullet$ & Confirmability & Case study protocol & $\begin{array}{l}\text { Careful selection of } \\
\text { interview participants to } \\
\text { include all relevant } \\
\text { stakeholders }\end{array}$ & $\begin{array}{l}\text { Careful recording } \\
\text { and storage of data } \\
\text { Digital recordings }\end{array}$ & $\begin{array}{l}\text { Grid of analysis as } \\
\text { common frame of } \\
\text { reference between } \\
\text { researchers } \\
\text { Data audit for bias and } \\
\text { distortion }\end{array}$ \\
\hline
\end{tabular}

*Two of the authors analyzed 10 interview transcripts each and compared their respective analyses and additional themes in order to reach agreement and increase intercoder reliability, calculated at more than $70 \%$, which is an acceptable level of agreement (Carey, Morgan, \& Oxtoby, 1996). 100\% agreement was then reached through discussions.

Table 5: Power Relationships at the Dyadic Level

\begin{tabular}{|c|c|c|c|}
\hline Relationship & Buyer Power & Supplier Power & Relationship Type \\
\hline B.F. - A1 & HIGH & LOW & Buyer dominance \\
\hline B.F. - A1.1 & HIGH & LOW & Buyer dominance \\
\hline B.F. - A2 & HIGH & MEDIUM & Buyer dominance \\
\hline B.F. - A3 & HIGH & LOW & Buyer dominance \\
\hline B.F. - A4 & HIGH & LOW & Buyer dominance \\
\hline B.F. - A5 & HIGH & LOW & Buyer dominance \\
\hline B.F. - A6 & HIGH & LOW & Buyer dominance \\
\hline B.F. - B1 & LOW & HIGH & Supplier Dominance \\
\hline B.F. - B2 & MEDIUM & HIGH & Supplier dominance \\
\hline B.F. - C1 & LOW & HIGH & Supplier Dominance \\
\hline B.F. - C2 & HIGH & LOW & Buyer dominance \\
\hline
\end{tabular}

Table 6: Dominant Relationship Types With Big Food

\begin{tabular}{|c|c|c|}
\hline $\begin{array}{c}\text { Relationship } \\
\text { Type }\end{array}$ & Critical Themes & \multicolumn{1}{c|}{ Illustrative Quotations } \\
\hline BUYER & $-\quad \begin{array}{l}\text { Buyer represents high } \\
\text { proportion of supplier's }\end{array}$ & $\begin{array}{l}\text { A.2 "For crop A, there is nowhere else for them to go." } \\
\text { A.6 "The vast majority of crop A we grow are for BF." }\end{array}$ \\
\hline
\end{tabular}




\begin{tabular}{|c|c|c|}
\hline & $\begin{array}{ll} & \text { revenue } \\
\text { - } & \text { Lack of alternatives to } \\
\text { supply } \\
\text { - } \quad \text { Captive supplier } \\
\text { situation } \\
\text { - } \quad \text { Multiple suppliers } \\
\text { available }\end{array}$ & $\begin{array}{l}\text { A.1 "We are sole suppliers, we are not supplying any other customer of } \\
\text { A." } \\
\text { A. } 2 \text { "I have never added up what capital is behind the thousands of tons } \\
\text { that we supply, I don't quite have a figure, but it's millions and millions." } \\
\text { A.4 "BF regards a contract over a year as a liability." } \\
\text { B.F. "There have been some tense contract negotiations over the last few } \\
\text { years." } \\
\text { C. "Our current business was initiated by BF about } 8 \text { or } 9 \text { years ago to } \\
\text { provide a better avenue for their supply of crop C into the future." } \\
\text { "We used to supply } 100 \% \text { of crop C for the brand but then BF chose to } \\
\text { have more suppliers because they felt that having one supplier wasn't the } \\
\text { most cost effective and least risky way." } \\
\text { "Most of their contracts are for short-term supply and they are reluctant } \\
\text { to sign long-term agreements." }\end{array}$ \\
\hline $\begin{array}{c}\text { SUPPLIER } \\
\text { DOMINANCE }\end{array}$ & 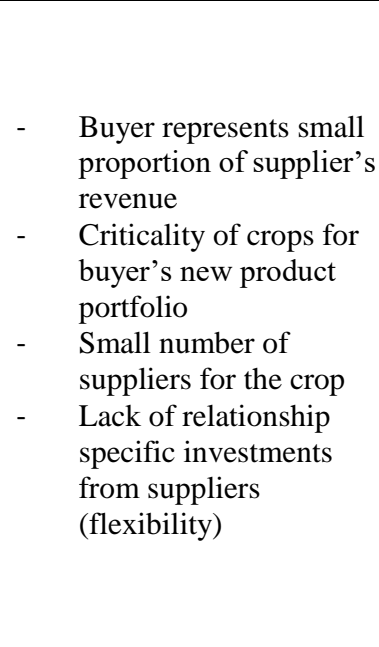 & $\begin{array}{l}\text { B.F. "In certain ways crop B suppliers are very tactical. They play the } \\
\text { market. If the prices go up for something they will all go there, if prices } \\
\text { go down..." } \\
\text { "B is a crop you can go in and out, it doesn't have the capital } \\
\text { requirements of other crops. We have more of a battle in our hands to } \\
\text { have these suppliers keep growing B." } \\
\text { B.1 "Because this area is a big producer of B, there has been an interest } \\
\text { for B.F. to speak and trade with us." } \\
\text { "There are other commercial opportunities for us suppliers on the open } \\
\text { market." } \\
\text { C. } 2 \text { "From their point of view they want the security of supply because } \\
\text { crop C is important for their economic viability." } \\
\text { "They are expanding their requirement of C because of their new product } \\
\text { portfolio and their main priority is to safeguard future suppliers." } \\
\text { "The motivation to supply BF is very minimal because we aren't in crop } \\
\text { C for them. It just happens that BF is a useful way of selling the leftovers } \\
\text { of crop C." } \\
\text { "The longer the contract, the bigger the risk to us as merchants." }\end{array}$ \\
\hline
\end{tabular}

Table 7: Horizontal Supplier-Supplier Relationships in the Different SCs

\begin{tabular}{|c|c|c|c|}
\hline & $\begin{array}{c}\text { General Description From } \\
\text { Cases }\end{array}$ & Buyer's Strategic Intent & $\begin{array}{l}\text { Supplier-Supplier Relationship } \\
\text { Characteristics Observed }\end{array}$ \\
\hline FOOD A & $\begin{array}{l}\text { Suppliers are } \\
\text { geographically dispersed } \\
\text { but organized in supplier } \\
\text { groups. Group sizes and } \\
\text { organization vary. Head of } \\
\text { groups are the main points } \\
\text { of contact for B.F. }\end{array}$ & $\begin{array}{l}\text { Exert competitive pressure } \\
\text { between supplier groups to keep } \\
\text { prices low, high quality, and } \\
\text { stimulate compliance. } \\
\text { Reduce supply and environmental } \\
\text { risks by sourcing from multiple } \\
\text { large suppliers in different } \\
\text { regions. } \\
\text { Stimulate performance and } \\
\text { transparency around newly } \\
\text { introduced environmental and } \\
\text { social projects by having } \\
\text { suppliers collaborate (e.g., } \\
\text { supplier group training on carbon } \\
\text { measurement tool). }\end{array}$ & $\begin{array}{ll}\text { - } & \text { Collaborative relationships and } \\
\text { information sharing within groups } \\
\text { - Some individual affinities across } \\
\text { groups but limited amount of } \\
\text { information sharing as proprietary } \\
\text { information is viewed as competitive } \\
\text { advantage } \\
\text { - Head of groups are in charge of } \\
\text { negotiating contracts for the group, } \\
\text { passing down sustainability } \\
\text { requirements, and managing the } \\
\text { relationships between group suppliers. } \\
\text { Solidarity between suppliers around } \\
\text { degrading quality of relationship and } \\
\text { increasing requirements } \\
\text { Coopetitive relationships }\end{array}$ \\
\hline FOOD B & $\begin{array}{l}\text { Limited number of } \\
\text { suppliers in two distinct } \\
\text { geographical locations. }\end{array}$ & $\begin{array}{l}\text { Reduce supply and environmental } \\
\text { risks by sourcing from two main } \\
\text { supplier groups in separate } \\
\text { regions. } \\
\text { Increase performance by making } \\
\text { the two main suppliers compete to } \\
\text { supply the most environmentally } \\
\text { efficient farm-to-factory services. }\end{array}$ & $\begin{array}{ll}\text { - } & \begin{array}{l}\text { Limited interaction between supplier } \\
\text { groups }\end{array} \\
\text { - } & \text { Cordial relationships between supplier } \\
\text { groups as perception of being different } \\
\text { types of suppliers (complementary) } \\
\text { Transparency within supplier groups } \\
\text { but no information sharing between } \\
\text { groups } \\
\text { - }\end{array}$ \\
\hline FOOD C & $\begin{array}{l}\text { One dedicated supplier and } \\
\text { other ad hoc suppliers } \\
\text { selling leftover supplies of } \\
\text { C that couldn't be sold to }\end{array}$ & $\begin{array}{l}\text { Reduce costs of sustainability by } \\
\text { tapping into suppliers' previous } \\
\text { experience and certifications } \\
\text { acquired for other buyers. }\end{array}$ & $\begin{array}{ll}\text { - } & \text { Knowledge of identity of other } \\
\text { suppliers but no interaction } \\
\text { - } \quad \text { C2 negatively perceive other suppliers }\end{array}$ \\
\hline
\end{tabular}




\begin{tabular}{|l|l|l|ll|}
\hline & $\begin{array}{l}\text { retailers. Limited continuity } \\
\text { of supply base except for } \\
\text { C2 } 2\end{array}$ & $\begin{array}{l}\text { Stimulate competition between } \\
\text { C2 and other suppliers to get } \\
\text { better prices and reduce risks. }\end{array}$ & $\begin{array}{l}\text { Minimal explicit information sharing } \\
\text { Competitive relationship }\end{array}$ \\
\hline
\end{tabular}


Table 8: Power Influences on SSC Relationships

\begin{tabular}{|c|c|c|}
\hline & Description & Illustrative Quotations \\
\hline $\begin{array}{l}\text { Contractual arrangements } \\
\text { Sustainability requirements in contract }\end{array}$ & $\begin{array}{l}\text { Additional clauses in contracts related to environmental and } \\
\text { social goals }\end{array}$ & \multirow{4}{*}{$\begin{array}{l}\text { A.4 "With sustainability in the contracts, it's more a } \\
\text { policing way." } \\
\text { "This is not the sort of negotiations need to be doing. } \\
\text { This is hugely short termist. They are very short-termist } \\
\text { considering what they are trying to achieve the other side } \\
\text { on the carbon reduction and sustainability." } \\
\text { B.F. "I think at the moment it is a real struggle to get } \\
\text { supplier B1 and B2 to contract." }\end{array}$} \\
\hline Tense contractual negotiations & Difficult to reach agreement on prices and contract clauses & \\
\hline Contract length & Short-term contracts for commercial flexibility & \\
\hline Contractual uncertainty & Difficult to contract with dominant suppliers & \\
\hline \multicolumn{3}{|l|}{ Planning and goal setting } \\
\hline Multiplying sustainability requirements & $\begin{array}{l}\text { Increasing number of environmental and social projects to be } \\
\text { completed by suppliers }\end{array}$ & \multirow{4}{*}{$\begin{array}{l}\text { C. } 2 \text { "They have introduced a huge raft of requirements." } \\
\text { A. } 1 \text { "We tend to be more the recipients of their } \\
\text { expectations." } \\
\text { A.1 "They are always looking for the next problem or } \\
\text { the next challenge or the next opportunity and it is good } \\
\text { to work with companies of that caliber." }\end{array}$} \\
\hline Short- vs. long-term orientation & $\begin{array}{l}\text { Sustainability goals are set over period of } 5+\text { years and } \\
\text { commercial goals are set every year }\end{array}$ & \\
\hline Unilateral decisions & $\begin{array}{l}\text { No involvement of suppliers in the development of sustainability } \\
\text { initiatives }\end{array}$ & \\
\hline Sustainability leadership & $\begin{array}{l}\text { Buyer's access to new technology and knowledge on } \\
\text { sustainability }\end{array}$ & \\
\hline \multicolumn{3}{|l|}{ Implementation process \& monitoring } \\
\hline Sustainability push & $\begin{array}{l}\text { Top-down implementation and enforcement of sustainability } \\
\text { projects }\end{array}$ & \multirow{5}{*}{$\begin{array}{l}\text { B.F. "It's definitely a push for sustainability." } \\
\text { "We don't want to keep shoving it down their throats." } \\
\text { B. } 2 \text { "And so in conjunction with the requirement } \\
\text { eventually to carry out a carbon audit, they're really } \\
\text { emphasizing the sustainability message when we meet } \\
\text { them." }\end{array}$} \\
\hline Supplier auditing & $\begin{array}{l}\text { Detailed and systematic examination of suppliers' environmental } \\
\text { and social practices }\end{array}$ & \\
\hline Supplier training & $\begin{array}{l}\text { Organization of specific sessions and meetings with external } \\
\text { facilitator to teach suppliers how to deal with new requirements }\end{array}$ & \\
\hline Delegation & Suppliers responsible for ensuring compliance of other suppliers & \\
\hline Minimum compliance & Suppliers not willing to go beyond box-ticking exercise & \\
\hline $\begin{array}{l}\text { Communication \& information sharing } \\
\text { Lack of sustainability conversation }\end{array}$ & Sustainability issues are not part of daily informal conversation & \multirow{4}{*}{$\begin{array}{l}\text { B.F. "They are not terrifically disciplined in terms of } \\
\text { data collection." } \\
\text { A. } 2 \text { "Sustainability is another one of those terms that } \\
\text { they want us to use because it's fashionable." }\end{array}$} \\
\hline Buyer's terminology & $\begin{array}{l}\text { Terms and issues part of the sustainability agenda defined by the } \\
\text { buyer }\end{array}$ & \\
\hline Formal sustainability meetings & $\begin{array}{l}\text { The main platform to discuss sustainability issues is biannual } \\
\text { meetings organized by the buyer }\end{array}$ & \\
\hline Forensic supplier data collection & $\begin{array}{l}\text { Initiatives aimed at gathering data from suppliers about costs and } \\
\text { environmental and social impacts }\end{array}$ & \\
\hline \multicolumn{2}{|l|}{ Commitment } & \multirow{2}{*}{$\begin{array}{l}\text { B.2 "Sustainability might take a back seat until they can } \\
\text { encourage production of more B from their suppliers." } \\
\text { "We haven't spent a lot of time on it so far." }\end{array}$} \\
\hline Suppliers' sustainability investments & $\begin{array}{l}\text { Upfront investments made by suppliers to comply with buyer's } \\
\text { sustainability requirements }\end{array}$ & \\
\hline
\end{tabular}




\begin{tabular}{|c|c|c|}
\hline Minimum efforts & $\begin{array}{l}\text { Limited amount of time and investment spent by suppliers to } \\
\text { address buyer's sustainability requirements }\end{array}$ & \\
\hline Supplier resistance & Unwillingness to comply or engage in further requirements & \\
\hline Benefits and risks sharing & & \multirow{6}{*}{$\begin{array}{l}\text { A.1 "(The requirements) are putting pressure on us as a } \\
\text { business." } \\
\text { "They are guiding us down that route and are putting } \\
\text { pressure on us to move that way, without having to pay } \\
\text { us a great deal more money." } \\
\text { C. "To achieve these environmental goals, you have to } \\
\text { make some investments but of course they don't want to } \\
\text { be making those investments." }\end{array}$} \\
\hline Buyer's reputation benefits & $\begin{array}{l}\text { Buyer's enhanced visibility and reputation for addressing } \\
\text { sustainability issues (e.g., awards, press coverage) }\end{array}$ & \\
\hline Buyer's financial benefits & $\begin{array}{l}\text { Buyer's returns on investment and cost reduction from } \\
\text { encouraging environmental and social compliance from suppliers }\end{array}$ & \\
\hline Rising supplier costs & $\begin{array}{l}\text { Small return on capital and upfront investment with no increase in } \\
\text { prices }\end{array}$ & \\
\hline Supplier differentiation & Advantage of being compliant when dealing with other customers & \\
\hline No sustainability reward system & $\begin{array}{l}\text { Price negotiations and bonuses not linked to sustainability } \\
\text { requirements }\end{array}$ & \\
\hline Expectations \& continuity & & \multirow{5}{*}{$\begin{array}{l}\text { A.1 "If we want to be a supplier of theirs, which we have } \\
\text { been for many years, we need to and want to go with } \\
\text { them." } \\
\text { A.5 "Growers are saying, "Why would I want to do this? } \\
\text { I have got enough on my plate without having to fill in } \\
800 \text { lines of Excel spreadsheets, which isn't even } \\
\text { finished yet." }\end{array}$} \\
\hline Expectations of compliance & Buyer's expectation to reach $100 \%$ compliance from growers & \\
\hline Shared responsibility & $\begin{array}{l}\text { Desire that decisions and responsibility will be more equally } \\
\text { shared between buyer and suppliers }\end{array}$ & \\
\hline Commercial necessity & $\begin{array}{l}\text { Reason for staying in the relationship and complying driven by } \\
\text { high dependence on buyer }\end{array}$ & \\
\hline Supplier disenchantment & $\begin{array}{l}\text { Perception of degrading relationship quality and general } \\
\text { discontent about terms of relationship }\end{array}$ & \\
\hline
\end{tabular}

Themes related to supplier power 


\section{FIGURES}

Figure 1: Map of Dyadic and Horizontal Relationships

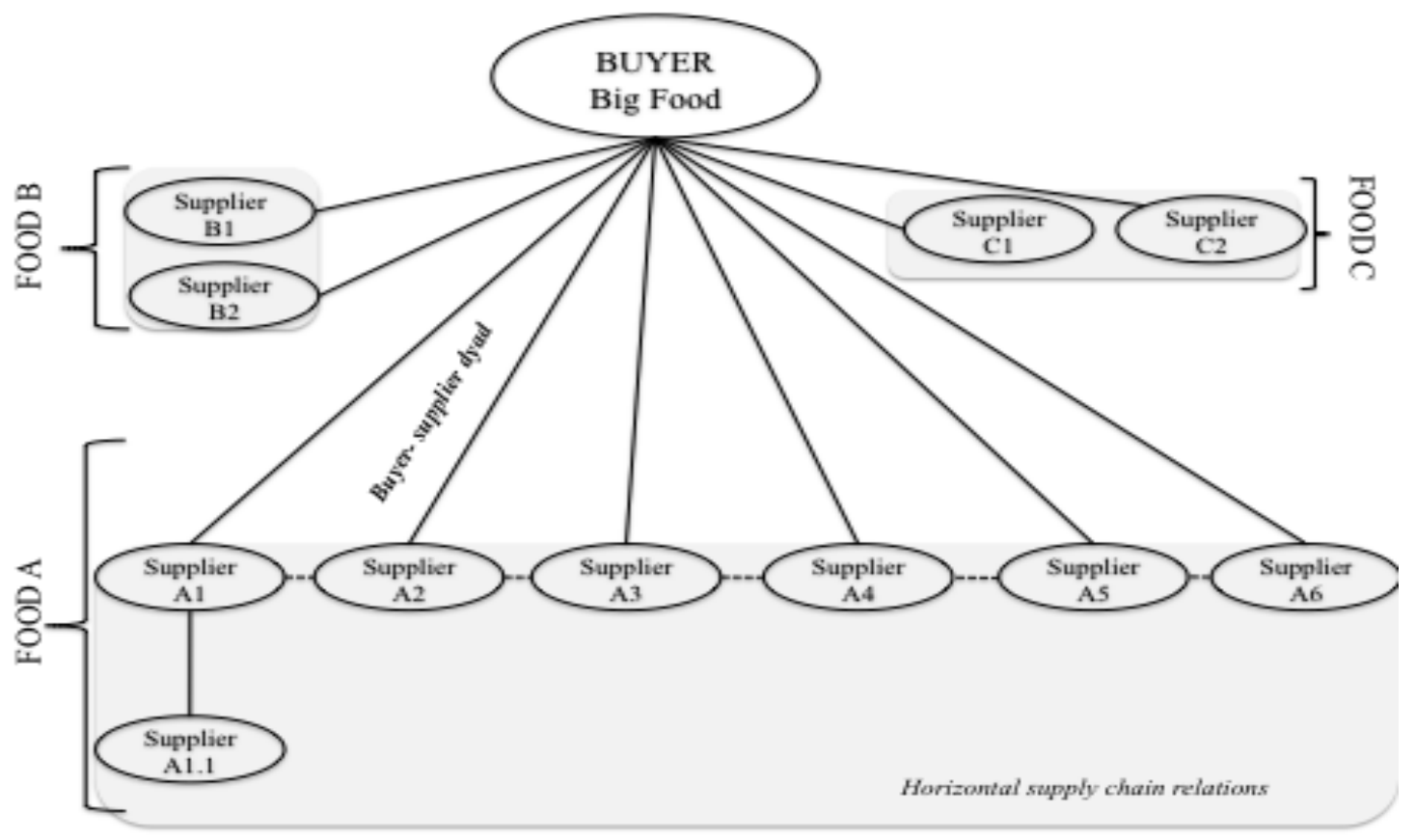

Figure 2: Evidence of Shift to Interdependence

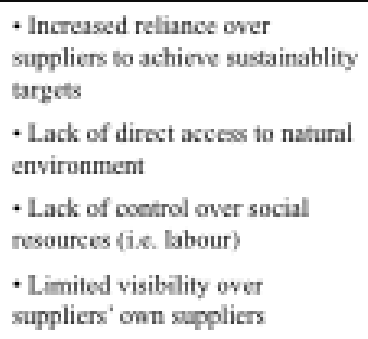

- Importance of beaver for accessing knowledge and skills to manage sustainability requirements

- Incentives to enter long-term agreements 
Figure 3: Mapping of Relationships in Terms of Power/Dependence

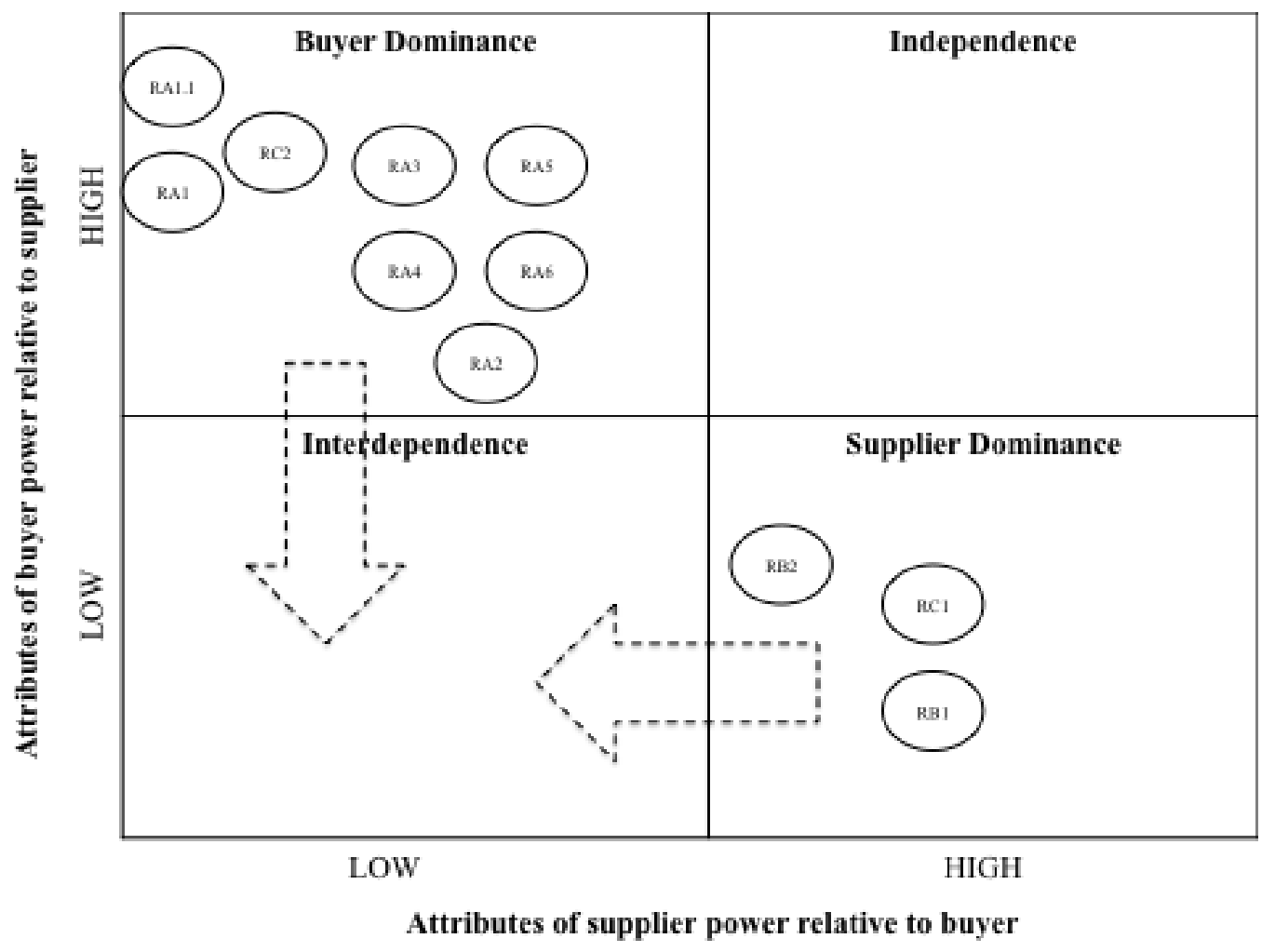

